San Jose State University

SJSU ScholarWorks

Master's Theses

Master's Theses and Graduate Research

Summer 2014

\title{
Radio:Reaching Young Adult Audiences, What are the Challenges and Opportunities for Radio Programmers in Cultivating Young Adult Audiences in the Current Media Environment?
}

Joel David Abramson

San Jose State University

Follow this and additional works at: https://scholarworks.sjsu.edu/etd_theses

\section{Recommended Citation}

Abramson, Joel David, "Radio:Reaching Young Adult Audiences, What are the Challenges and Opportunities for Radio Programmers in Cultivating Young Adult Audiences in the Current Media Environment?" (2014). Master's Theses. 4447.

DOI: https://doi.org/10.31979/etd.jj2m-tzd2

https://scholarworks.sjsu.edu/etd_theses/4447

This Thesis is brought to you for free and open access by the Master's Theses and Graduate Research at SJSU ScholarWorks. It has been accepted for inclusion in Master's Theses by an authorized administrator of SJSU ScholarWorks. For more information, please contact scholarworks@sjsu.edu. 


\title{
RADIO: REACHING YOUNG ADULT AUDIENCES, WHAT ARE THE CHALLENGES AND OPPORTUNITIES FOR RADIO PROGRAMMERS IN CULTIVATING YOUNG ADULT AUDIENCES IN THE CURRENT MEDIA ENVIRONMENT?
}

\author{
A Thesis \\ Presented to \\ San José State University \\ In Partial Fulfillment \\ of the Requirements for the Degree \\ Masters of Arts
}

The Faculty of the Department of Television, Radio, Film and Theatre

by

Joel D. Abramson

August 2014 
(C) 2014

Joel D. Abramson

\section{ALL RIGHTS RESERVED}


The Designated Thesis Committee Approves the Thesis Titled

RADIO: REACHING YOUNG ADULT AUDIENCES, WHAT ARE THE CHALLENGES AND OPPORTUNITIES FOR RADIO PROGRAMMERS IN CULTIVATING YOUNG ADULT AUDIENCES IN THE CURRENT MEDIA ENVIRONMENT?

\author{
by \\ Joel D. Abramson \\ APPROVED FOR THE DEPARTMENT OF TELEVISION, RADIO, FILM AND \\ THEATRE \\ SAN JOSÉ STATE UNIVERSITY
}

August 2014

Mr. Mike Adams Department of Television, Radio, Film and Theatre

Dr. Kimb Massey Department of Television, Radio, Film and Theatre

Mr. Nick Martinez Department of Television, Radio, Film and Theatre 


\begin{abstract}
RADIO: REACHING YOUNG ADULT AUDIENCES, WHAT ARE THE CHALLENGES AND OPPORTUNITIES FOR RADIO PROGRAMMERS IN CULTIVATING YOUNG ADULT AUDIENCES IN THE CURRENT MEDIA ENVIRONMENT?
\end{abstract}

As young adults have adopted the use of digital new media technologies, previous scholarly research has predicted a lack of interest by young adults in traditional media, including radio. This waining interest in traditional media by young adults has also been reported in the popular press. An abandonment of radio by young adults could bring about an eventual decline in audience, resulting in adverse economic effects to the broadcast radio industry and related industries, including a decrease in radio revenues, the deflation in the value of radio properties, and potential job loss. This research examined the challenges radio programmers and marketers feel they are having in reaching out to and growing young adult audiences in the face of competition from new media and new media technologies as well as new opportunities for programming and marketing that these new media present. This research surveyed websites and interviewed radio broadcasters in the San Francisco Bay Area who demonstrated success in marketing to young adults in an attempt to ascertain the challenges and new opportunities in reaching and cultivating radio listeners is presented by new media. It was found that these San Francisco Bay Area radio stations are using new media tools to market and program to young adult listeners, and that these tools are key in keeping the radio medium robust. 


\section{Table of Contents}

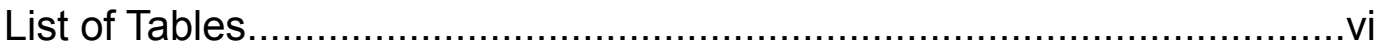

List of Figures.....................................................................................

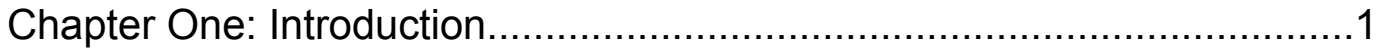

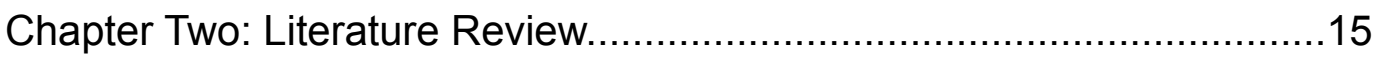

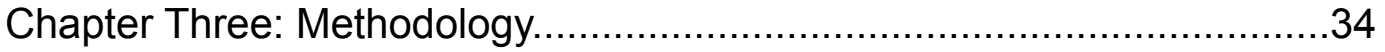

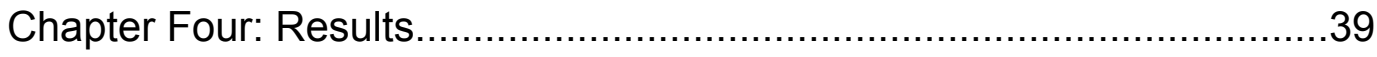

Part One, Quantitative Research................................................39

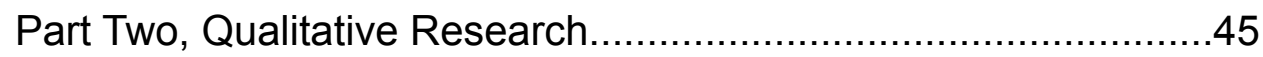

Chapter Five: Analysis of Data and Conclusions..................................57

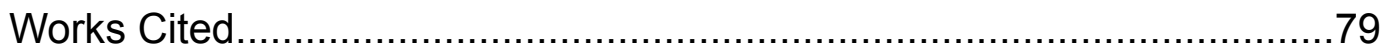




\section{List of Tables}

Table 1. Internet Use Trend by American Adults 2002-2005.

.20

Table 2. Internet Trend by American Adults 2000-2009. Do you Use the Internet, at least occasionally?......................................21

Table 3. Percentage of Americans who are Internet Users....................22

Table 4. Use of Internet by Young Adults.........................................23

Table 5. Percentage of Americans who Own a Smartphone...................24

Table 6. Percentage of Smartphone Ownership by Age .......................25

Table 7. Percentage of Ownership of Tablets..................................26

Table 8. Importance of Internet and Texting for Maintaining Social Relationships for Young Adults by Age..............................27

Table 9. Persons Age 12+ who have a Social Networking Site................28

Table 10. Most Important Social Networking Sites for Teens..................29

Table 11. Persons 12+ Awareness of on line Music Sites.......................30

Table 12. Percent Who Listened to On Line Music Sites by Age..............31

Table 13. Radio Revenue, in Billions...................................................32

Table 14. Website Digital Media Tools of Successful San Francisco Area Radio Stations in 18-34 year old Demographics 43 


\section{List of Figures}

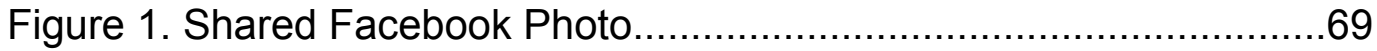


Chapter One: Introduction

"I'm in a war, a cultural war", Howard Stern (Carr 1)

When Howard Stern declared his involvement in a culture war to a New York Times reporter, he was referring to his battle over the content of his radio show. However, the self described "King of All Media" (Stern) might have well been describing other challenges facing radio today. One of the biggest changes in recent broadcast history for radio was the enactment of the Telecommunications Act of 1996. Radio broadcasters who were once limited to the number of stations they could own were now unrestricted in station ownership numbers. Radio broadcasters were merged, and fewer station owners meant that business strategies of radio were also consolidated. Radio formats became brands of the parent companies, such as Clear Channel's Star FM pop format, Cumulus Radio's Nash FM country format and CBS Radio's Jack FM pop format. Ultimately this radio format brand consolidation led to fewer types of formats on radio overall, with most major markets sporting multiple national brands of format, supplanting locally derived formats.

Another effect of the radio consolidation has been the advent of new radio technologies that allowed for a new type of networking called voice tracking. This technology not only allowed an announcer to pre-record a show in much less time, it allowed the parent company to broadcast the announcer on multiple 
stations in multiple markets. An announcer could appear to be broadcasting live at a particular station, when in fact the performance was recorded previously in another location. The result of consolidation has been fewer musical choices for listeners of radio and fewer voices being heard on radio.

However, not all of the challenges to radio have been self-inflicted. Competition for audience has come in the form of other media. Radio has always competed for media audience with film and print, but a dramatic adaptation in radio programming happened when television supplanted radio as the public's preferred medium of broadcast news and entertainment. Many of the radio performers found television a more lucrative endeavor as well. Thus, many radio shows of that time migrated to television. Faced with this drain in content from radio to television, radio programmers found that music and talk formats broadcast around the clock could replace the convention of half hour and hour blocks of shows that once populated the radio dial.

Like the challenge of deregulation of the nineties and the emergence of television before that, radio faces another challenge from new digital technologies that take on many forms. Computers, smartphones, and tablets represent a new variety of digital platforms for audiences to obtain and exchange information, news, and entertainment. The growth of these new media technologies has been noticed by the public and the popular press. An article in entertainment trade magazine Variety went as far to claim that radio "owners 
know it's headed into the dumper" (Lefsetz), citing the lack of innovation of new music on the radio and the competition from new media.

Long before the advent of these new media sources, platforms, and software, Marshal McLuhan expressed that "A new medium...never..leave(s) the old one in peace. It never ceases to oppress the older media until it finds new shapes and positions for them" (174). Rather than sending radio to the dumper, it may be that new media is challenging and re-shaping traditional media, including radio.

Data confirms the perception of the growth of new media platforms with a five hundred percent growth in smartphone ownership in the five years since 2009 , and a leap in tablet ownership in two years from 17 percent to 39 percent (Edison Research and Triton Digital). This same report also shows an alarming trend when it comes to young adults. Among the overall population, AM and FM radio is the top source for keeping up-to-date with music. However, among persons twelve through twenty four, AM and FM radio ranks fourth in sources listed to keep up-to-date with music, ranking behind YouTube, Pandora, and Friends and Family. Scholarly research has also confirmed evidence that young audiences tend to prefer new media over traditional radio in many cases. A study found that traditional radio has a limited utility in the new digital environment where young adults are used to flexibility and choice, including playlist technology for music (Albarran, et. al., 92-101). 
Beyond their adoption of new media, young adult audiences also represent the future for all traditional media including radio, for two primary reasons. First, if young adults are choosing new media over traditional media choices including radio, this would imply for the first time in decades that the newest consumers of traditional media would be leaving the market for a preference of the user designed experience of new media. Secondly as older audiences age out, younger audiences need to replace them if traditional media is going to maintain numbers close to current audience levels. It would seem that traditional media, including radio, would be losing audiences as young listeners find a fascination for new media. This subsequently produces an audience "drain" as fewer young listeners adopt radio as audiences age. Dr. McLuhan (174) questions what "shape" radio may find itself in in the new media environment. Additionally, what can radio do in order to gain and attract young audiences while still maintaining popularity or even growth when faced with the competition of the new media? The question is: What are the challenges and opportunities for radio programmers in cultivating young adult audiences in the current media environment?

To begin to answer this question, it is necessary to define radio. A mere decade ago, radio was easy to define. The word radio meant the apparatus from which one listened to broadcasts and the means of getting the broadcasts to the device, radio transmission. Radio also described the activity of broadcasting audio programming to audiences (Oxford University Press). 
Today, our experience of radio is changed. Audiences no longer need a traditional radio receiver or terrestrial AM or FM broadcast technology to listen to the radio. One can hear radio via other devices such as a computer, tablet or smartphone over other types of radio transmission protocols such wireless internet or the cell phone network. Consumers can receive radio programming over the television cable network, various forms of wired internet technologies and consumers can also receive radio programming over satellite technology.

Many would contend that radio is no longer a broadcast activity, but instead programming is tailored and targeted to distinct demographic groups, a phenomenon referred to as narrowcasting (Merriam-Webster). Radio industry professionals and scholars point out that radio now narrowcasts rather than broadcasts, targeting programming to specific demographic groups rather than to the overall population. Still, these messages are broadcast from one location to many locations at once, and although today's radio formats are narrowcasted towards audiences relative to radio programming of days past, the actual content is still broadcast, conforming with the traditional definition for the word radio.

There are also a number of applications, activities, and businesses that call themselves radio, iHeart radio, iTunes radio, and Sirius/XM radio among them. There is also online radio, which includes content streamed from traditional radio stations, or from independent online broadcasters producing content from stations that exist only online. There are also the online music services that include Pandora, iHeart, iTunes, Rhapsody, Spotify, Google Play All 
Access, Slacker, Grooveshark, Radio.com, Tuneln Radio, Last.fm, Rdio, Songza, and Stitcher. Consumers now have a choice of a wide variety of devices, receiving transmissions over multiple forms of technologies, broadcasting and narrowcasting various types of audio programming.

In the face of the new technologies and the new activities of audio content providers and their listeners, a new definition of radio is needed to separate radio from a new millennium of radio-like activities. This new definition takes into account the source of the content, who and what defines the source of the content, and the potential for broadcast to multiple users. This definition may go against some of the currently accepted or assumed definitions of radio. Some audio services offer multi-functional hybrid programming where some of their services are radio and some of their services are not, as in the case of iHeartRadio which live streams radio stations and allows listeners to create their own programming (Clear Channel Music and Entertainment). This new definition is only describing the activity of listening to programming and not the device, technology or service to which one listens.

Radio must have a central point of broadcast origin such as a station or website. This is the traditional concept of broadcast, from one point to many. This does not exclude content that might be networked together such as a news broadcast that includes reports from around the world, as long as there is a central point at which these sources are rebroadcast to the audience. 
To be radio, the potential must exist for the content to be broadcast for multiple listeners to hear the same broadcast. Since the inception of the medium of radio, there has been the convention of point to point transmission. These two-way broadcast transmissions are telephony. A telephone call on a smartphone using radio frequencies to connect the callers is an example of the telephony most used today.

The content must be defined by someone other than the end user. The content provider can tailor the message for specific groups or individuals, and end users may provide feedback and suggest programming content, but if the content is defined by the end user, then it is not radio. There must be a central gatekeeper or host which screens user suggestions for appropriateness of rebroadcast to the audience. Content may originate from a human or may be automated; however, automated music recommender algorithms which use the end user's playlist to suggest new music content are excluded from the definition of radio as these algorithms are using data from the end user to design content specifically for that individual user.

Some of these activities in which users define their own playlists using on line music resources are a new way to shop for and add to one's virtual music library. The personal record or compact disc collection of yesterday that existed on a shelf in one's living room, now exists in the cloud for users to browse through and select. The personal access to ownership of music that one could buy at the local record store has been replaced by these services that allow 
access to music via the cloud for a subscription fee or by the user's acquiescence to listening to an occasional advertisement. These services are music access and music librarian services, not radio.

The length of the performance of music is no longer limited to the side of a record or the amount of songs that could fit on a compact disc. The limitation of the performance of music is the limitation of the length of ones' playlist. It is easy to see how the playback of an almost unlimited selection of music via the cloud could be confused with radio. That playlist may be very long, but it is not radio it is a playback of the user's music library and the user's access to music over the internet.

In this new definition, to be radio the content must be derived from a central point, controlled by a source other than the end user, and be broadcast to multiple end users. With this definition many of the new media radio stations are actually a radio-hybrid. Services such as Pandora or Spotify do broadcast "stations" to multiple listeners which does fit this new definition of radio. At the same time, these services also allow users to create their own station by use of direct listener feedback of "likes" and "dislikes" of songs. Pandora also uses a music recommender algorithm which scans the end user's library to recommend songs on the station, which the user can then like or dislike. In these cases the music selection is being controlled primarily by the end user for exclusive use of that user and is outside this new definition of radio. 
To further refine the discussion of the new definition of radio is a concept of micro-radio, where a single end user designing a station using these music recommender technologies could conceivably share their station with others. An activity that falls outside the new definition of radio, that of an end user defined "station", could be turned in to an activity that does fall within the new definition of radio if the end user shares their "station" with others. Pandora does allow single users to do exactly this, a single end user can design a "station" and then share that station with other Pandora users. This activity could be seen as radio, or micro-radio, where a user defines a station and shares it with a circle of friends.

To further answer the larger question of the challenges radio is facing in reaching and attracting young adult listeners, some critical terminology will be used.

A Station is the central point of broadcast, whether using radio frequency technology or web based technologies.

Market definitions will follow the definitions as described by Nielson Audio, formerly known as Arbitron, the major research company that collects data on radio listening. The radio trade terms that will be used are defined by Arbitron (1) and include the following terms:

Average Quarter Hours is the number of persons listening for a minimum of five minutes during a fifteen minute period. From this, a concept known as Quarter Hour Maintenance is derived to mean a format tactic to adjust listening habits in order to maximize Quarter Hour measurement. 
Day part is a time period, expressed in one hour increments.

Cume is the number of different persons listening during the course of a day part for a minimum of five minutes.

Rating is the audience expressed as a percentage of the total population.

Share is the percentage of those listening to radio in a survey area who are listening to a particular station.

Radio format definitions and the audiences they target will also follow Nielson/Arbitron protocols. As there are a large number of format definitions, we will define them by industry title, demographic target and musical or talk content as they appear in the thesis. In a broader sense, a radio format would include the overall content of the radio station's variety of media messaging and the messaging of the individuals of the station while interacting with listeners and advertisers. The over all messaging of a radio station, including the format, lis known as the station's brand and the act of branding is is the use of format and representatives of the station to market the radio station to a specific group or audience sometimes defined in terms of demographics and lifestyle behaviors.

A promotion is an event or activity enacted by the radio station or radio station personnel intended to reinforce the station image with listeners or prospective listeners, drive listeners to tune in to the station, or encourage listeners to participate in a station sponsored event or activity. The promotion is not and advertisement, however advertisers may participate in a promotion in order to help pay for the promotion. A specific type of promotion known as street 
is where station personnel engage the public in some type of face to face interaction outside of the station.

FCC is the Federal Communications Commission which regulates the broadcast of radio signals in the United States.

The Emergency Alert System(EAS) is a radio broadcast regulated by the FCC designed to alert listeners to public emergencies and keep listeners informed in the event of such emergencies. An Amber Alert of missing children are one such example of an EAS alert. The EAS is also used to keep the public informed during natural disasters such as severe weather events, and acts of war. The EAS conducts a series of weekly and monthly tests to insure the system is working properly. The EAS replaced the older Emergency Broadcast System(EBS) which performed the same function.

Broadcast Contours are a station's primary signal coverage area as designated by the FCC.

Terrestrial radio is a station which broadcasts with a signal that originates from a ground station and is picked up by a radio receiver, usually the end user or intended audience. Signals are broadcast on the AM or FM bands. Other bands such as shortwave or amatuer bands are excluded. Terrestrial signals can be analog or digital signals, however HD Radio which is a unique subset of terrestrial radio is always a digital signal. Terrestrial radio can include booster or translator technology which allows the broadcaster to fill in areas of weak signal strength within the broadcast contours of the station as set by the FCC. 
Satellite radio is a station which broadcasts with a signal that originates from a ground station and transmits to an earth orbit satellite, where it is then redirected to earth receivers, usually the end-user or intended audience. Satellite radio may also use terrestrial booster or translator technology to fill in broadcast contours.

A live and local performance is one that is produced in the market of the intended listeners, such as one that originates in the San Francisco market and is intended for and listened to in the San Francisco market. It is aired at the time of production, hence a live broadcast.

A syndicated show may be produced in the intended target market but is also broadcast to a location or locations other than the market of the broadcasts origination. Syndicated shows may actually be a live broadcast. However in some cases where shows are produced in an Eastern time zone and broadcast in a Western time zone, they may be recorded and re-broadcast.

A simulcast is a real time simultaneous rebroadcast of a radio signal over another station, band, satellite or the internet without alteration of the original broadcast content.

An App or Application is a software program that runs on a digital device such as a computer or Smartphone.

There are instances of industry programming jargon that may have different regional or situational meanings, one example is the term "listenable" which will be defined here as programming that is acceptable to mass audiences. 
"Authentic" is defined as programming that is targeted to a specific audience that may be defined further by specific ages, races or genders, sometimes at the exclusion of other ages, races or genders.

There are many tools that radio stations use to market to and maintain audience other than a station's broadcast signal. These tools may include station web links to email, blogs, and social media accessible on the station website or on a mobile application. On-line audio and video media players, podcasts, streaming players, apps and RSS feeds would also be included.

Music streaming services are apps that allow for radio stations to broadcast their contend over the internet using a dedicated software player. In some cases these broadcasts are simulcasts, where the entire broadcasted content from the original radio broadcast is also broadcast on the stream. In many other cases of music streaming, some of the content from the original radio broadcast is replaced on the stream. Typically radio stations might choose to replace originally broadcasted on air commercials with another set of commercials or other content on the stream. This is called commercial replacement.

A music channel is an app that allows for playback of songs over the internet. Typically users select specific songs, artists, playlists, or genres to play music over the Internet. Some examples of these are Spotify, Grooveshark and Last.fm. Users may also be able to give feedback to the channel in the form of likes, dislikes, skipping a song or repeating a song. Some music channels may 
collect the data of the user's feedback to recommend or avoid certain songs or artists.

Music recommender services are apps that play music of certain genres selected by the user. The user may then provide feedback or the service may also look at the user playlists available on the user's computer or music playing device, and then suggest music the user may like. The algorithm technology that allows for this is called audioscrobbling. Some examples of music recommender services are Pandora, MyStrands and iTunes Genius. There are also hybrid music recommender services owned by radio broadcasters that function as a combined music recommender service and a radio network that provides content to users from the broadcaster's network of stations. An example of this is iHeart Radio owned by Clear Channel Media and Entertainment.

A curated music channel accepts user feedback in forms such as likes, dislikes, replays of songs or skipped songs, or from music recommendation acquired from user playlist history or from audioscrobbling algorithms and adjusts the playlist and recommended playlist in accordance with the listener feedback.

With these definitions in hand, we should now look at the landscape of radio, new media, and what has currently been identified as the challenges radio faces in this new environment. 


\section{Chapter Two: Literature Review}

"...radio is one-sided when it should be two. It is purely an apparatus for distribution, for mere sharing out. So here is a positive suggestion: change this apparatus over from distribution to communication...That is to say, it would be if it knew how to receive as well as to transmit, how to let the listener speak as well as hear, how to bring him into a relationship instead of isolating him." Bertolt Bretch (Bretch 51)

From the very dawn of radio, some early broadcasters knew they had to engage an audience rather than just talk to them. As early at 1912, radio pioneer Charles Herrold broadcasts of the "Little Hams" program used many radio format conventions we know today to interact with his audience (Adams). Herrold's Wednesday night broadcasts to young amateur, or 'ham' radio enthusiasts, included a live announcer, the playing of recorded music, radio contests with winners being awarded prizes, telephone and mailed requests of music, and later, advertisements.

Charles Herrold scheduled his broadcasts at the time his intended audience was available. His broadcasts contained content that was specifically tailored for and intended for his specific audience. He gave them incentives to tune in by offering contests and prizes and added the additional interactive component of responding to listener requests. Herrold's broadcasts differed from many other transmissions of the day as other operators intended their broadcasts for either point-to-point communication or for a more vast mass audience not 
defined by demographics and whose broadcasts may have lacked the interactivity of Herrolds'. While the "Little Hams" programs were broadcast to a mass audience, they were by their very title intended for, or formatted for, the young early adopters of the technology of the day. Herrold used radio contests and listener requests to engage his young adult audience using the interactive components available to him at the time, the telephone and mail. By doing so, Herrold was not only an early broadcast pioneer, he had also discovered the potential of radio to target young adult listeners and engage them in a two way manner where the listeners help shape the content of the broadcasts and were rewarded for it. Although Herrold saw the potential for audience interaction, it would still take a while before audience interaction would become closer to what we know today.

Since the microphone was paired with the early radio transmitter, it is natural that radio talk shows would become a staple of early broadcasts. On the radio networks in the period of 1928 and 1929 there were 21 programs categorized as talk, public affairs, religious or miscellaneous talk (Munson). There were health talk shows, advice shows, women's beauty shows and religious shows among them, but most of these shows positioned the host and guests as experts, talking to or at the audience rather than interacting with them. Radio personality Art Baker, who hosted many shows throughout the 1930s and 1940s specialized in a particular category of radio show where a live studio audience would participate. NBC's "Breakfast Club" debuted in 1933 
which featured listener requests received via the mail (Munson). These are just a few examples of early talk and music formatted radio shows that tried to incorporate some form of audience interaction and participation.

In 1935, the radio show "America's Town Meeting on the Air" was broadcast in front of a live studio audience (Dunning). The show ran for two decades and featured lively debate of the topics of the day. That the show broadcasted in front of studio audiences was not a new convention. What made the "Town Meeting" broadcasts unique was that the live audience was encouraged to participate in the ongoing on air discussions. Radio programs that preceded discouraged hecklers, but during the "Town Meeting" lively interaction from the audience was expected. The show received nearly four thousand pieces of mail each week at its' peak. Nearly one thousand debate clubs were established across the nation to continue discussion off the air. The show eventually featured guests beamed in from remote locations from around the country to participate in the lively discussions.

Some may point to the "Town Meeting" broadcasts as being the first attempt at the interactive talk show format we know today, where heated debate is common and interaction from the audience is vital. Although the members of the studio audience were the only real-time audience members participating, there were other avenues such as the mail and the debate clubs that allowed radio audience members to interact with the broadcasts or the broadcasted content. 
Today there are close to 4012 talk or news/talk AM/FM radio stations and another 12,081 all sports AM/FM stations that include talk programming (Arbitron). These talk formatted stations encourage audience participation by interacting with listeners live on-air over the telephone, via social media, email, text messaging and twitter feeds. However talk, news/talk and sports/talk are only a fraction of the programming formats available to radio listeners. A variety of music programmed formats dominate the air waves today. One of the challenges of music radio programmed formats is in how to engage audience interaction similar to talk radio while maintaining their music formats.

This challenge of music format listener engagement may be particularly acute with stations that format to young adults. Earlier research pointed to a trend in preferences of young adults for new technologies over radio for listening to music (Albarran et. al,..). While listening to AM and FM radio in automobiles remains a primary function for radio overall, outside of their cars, young adults feel that radio may only be preferred as a source of news and information. Now that new media choices such as social media, YouTube and music player apps delivered over computers, smartphones and tablets are becoming available every day, audiences find that variety and listener defined choice may become important reasons to abandon radio.

This trend was further confirmed by a nationwide study which found that college students found a preference in these new technologies over radio in general (Ferguson, Greer, and Reardon). The emergence of internet and cell net 
connected devices such as computers, tablets and smartphones has added a new level of connectivity for young adults.

Radio station websites can be a valuable tool for promoting the station to listeners. A study conducted in 2003 revealed that television stations have discovered station websites to be an important promotional tool for reaching out to and engaging their audiences (Chan-Olmstead and $\mathrm{Ha}$ ). Prior studies inferred that broadcasters' websites were valuable primarily for the main reason of increasing revenues for the stations via advertising on these websites. It is now apparent that these websites are best used in support of promoting their main off-line business. Although the study cited is of television stations, it may have similar implications for radio broadcasters as well.

Radio stations have adopted the use of websites as a promotional tool. A content analysis of FM radio station websites conducted in 2002 found these websites to be underperforming in providing the kind of content listeners expressed a desire for (Potter). A survey of 500 radio station websites published in 2003 , concluded that much of the greatest potential that the internet provides for listener interaction and promotion were being underutilized at the time of the study (Pitts and Harms). These two studies confirm that early on in radio station's development of internet for promotional purposes, radio may have been slow to realize the potential of on line media technologies. With the adoption of the internet well established at the time, radio may have been behind the trend of keeping up with new technology. 
The traditional platforms for accessing the internet have been via desktop and laptop computers. According to a Pew Research study published in 2012, nearly three quarters of American adults own a laptop or desktop computer (Pew Research Center's Project for Excellence in Journalism). The rate of computer and laptop ownership has remained steady, with the study reporting the rate of ownership having not changed since 2007.

However over time, the use of the internet had been growing steadily. A Gallup survey indicates that the time spent on line by all adults has shown steady increases during a survey conducted between 2002 and 2005 (see Table 1).

\section{Table 1}

Internet Use Trend by American Adults 2002-2005

- Up to/More than 1 Hour

- Few Times a Week/Month Never 60

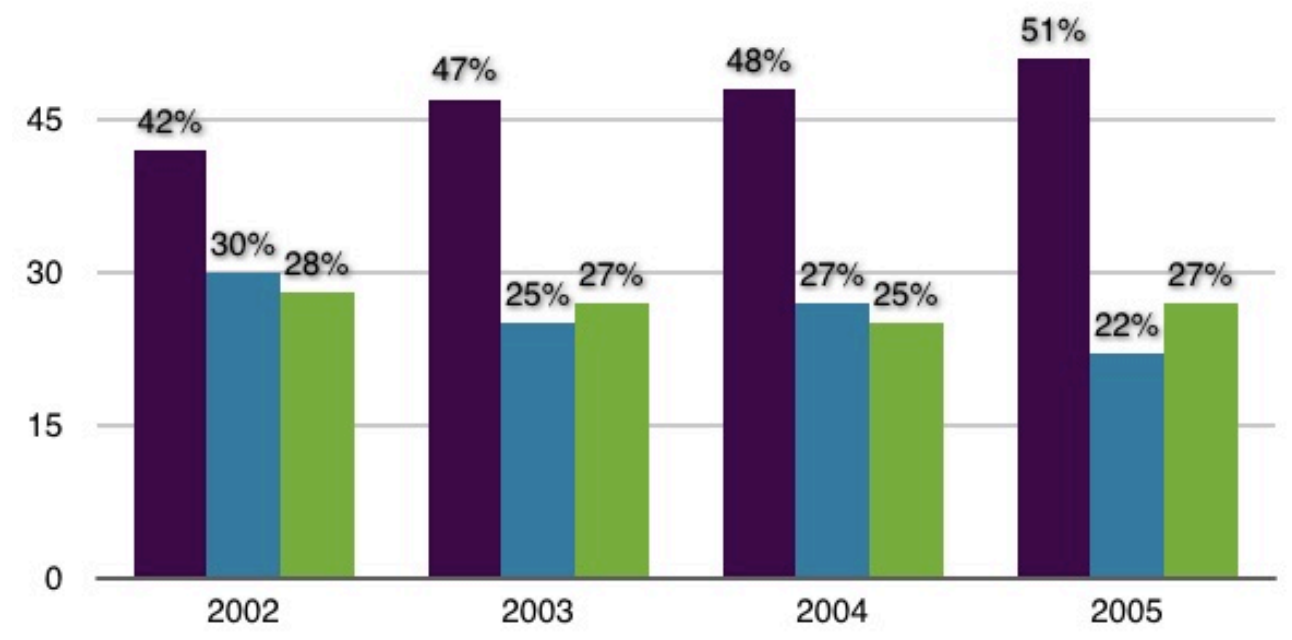

Source: Carroll, John. "Internet Catches More of Americans' Time”. Gallup. Web. Jan. 2006. 
Gallup found that in 2002, 42 percent of American adults used the internet daily. That percentage rose steadily through the survey period to 51 percent in 2005 . A study conducted by Pew Research between 2000 and 2009 indicated similar trend-lines with internet usage increasing while the percentage of respondents who reported not using the internet decreasing (see Table 2).

Table 2

Internet Trend by American Adults 2000-2009. Do you Use the Internet, at least occasionally?

- Uses Internet $\quad$ Does not Use Internet

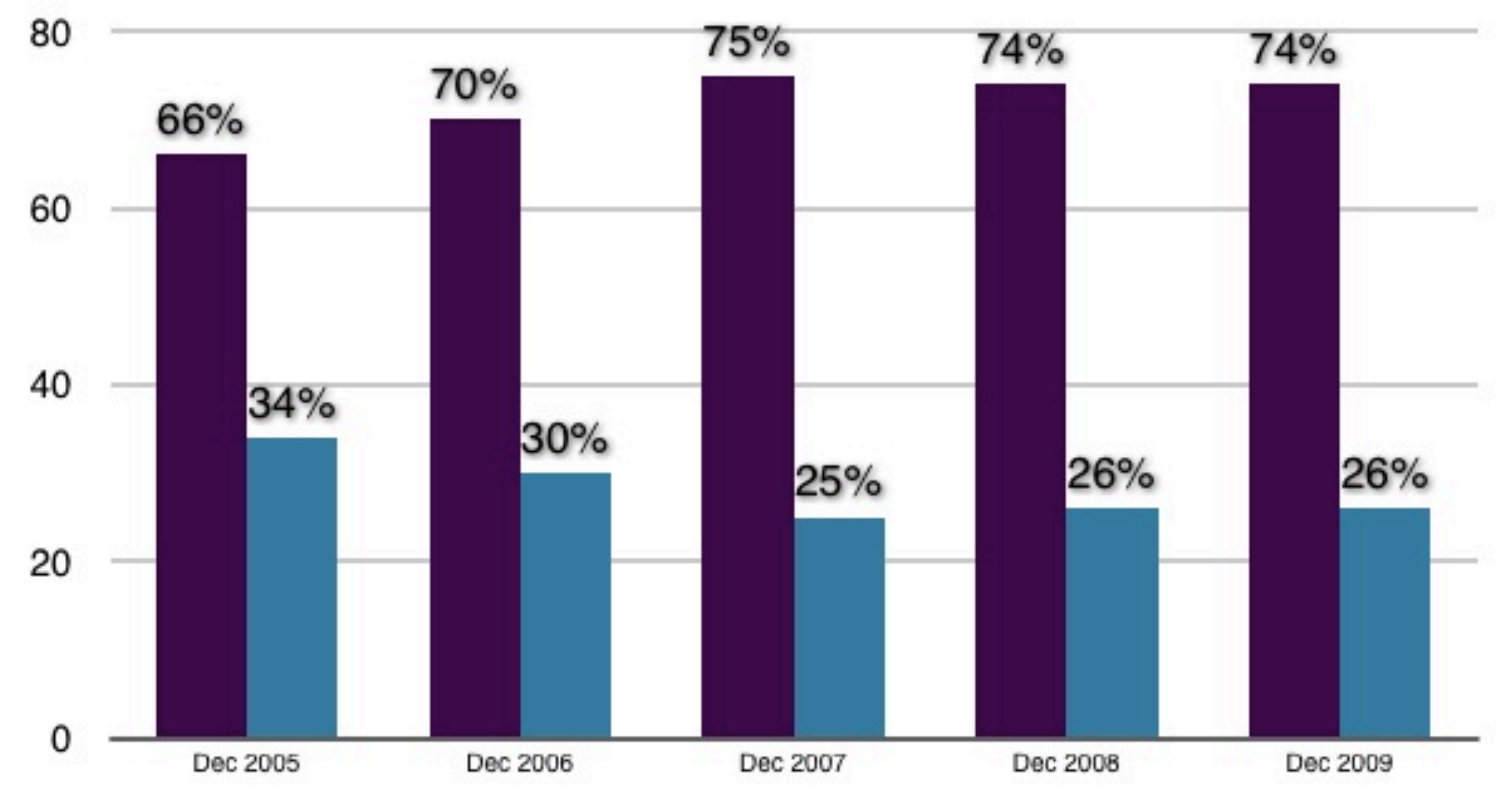

Source: Rainie, Lee. "Internet, Broadband and Cell Phone Statistics". Pew Internet \& Life Project, Jan. 2010, pdf. 
Another study conducted by the USC Annenberg School Center for the Digital Future from 2000 to 2012 also indicates similar upticks in Internet use (see Table 3).

Table 3

Percentage of Americans who are Internet Users

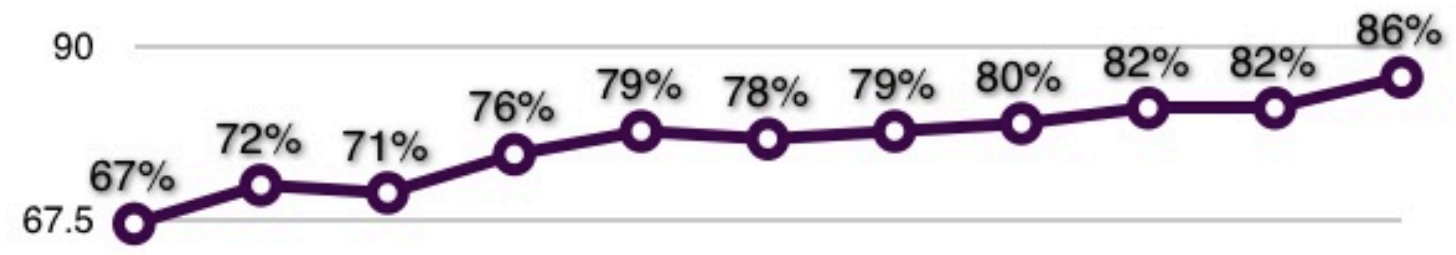

45

22.5

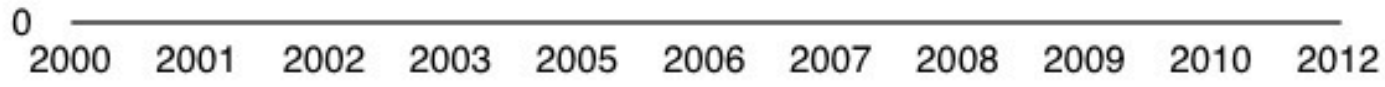

Source: University of Southern California. "The 2013 Digital Future Report" USC Annenberg School Center for the Digital Future. 2013. pdf.

A further look at the data from that same study shows that the use of the internet by young adults is even more pronounced (See Table 4) 
Table 4

Use of Internet by Young Adults

o 16-18 Year Olds o 19-24 Year Olds o 25-35 Year Olds

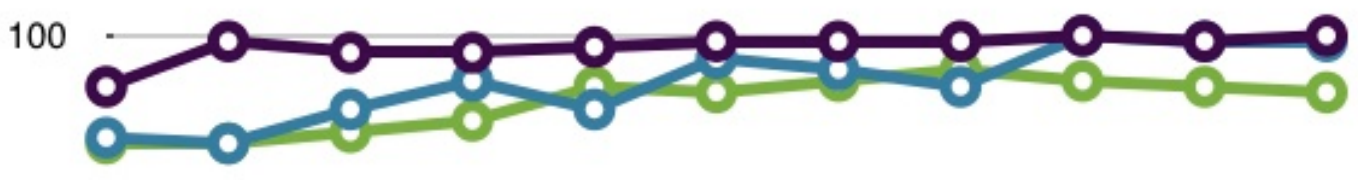

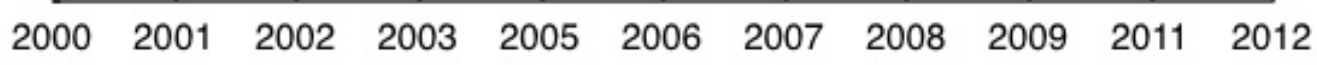

Source: University of Southern California. "The 2013 Digital Future Report USC Annenberg School Center for the Digital Future. 2013. pdf.

Use of the internet aside, how people are accessing the internet is also an important factor regarding the interests of radio. As desktop and laptop ownership has remained steady in the United States while internet use has increased, people may be spending more time in front of their computers. This rationale does not take into account the variety of new and portable technologies available to the public. Since radio is also a portable device with in-dash receivers in automobiles and the ability for audiences to listen to radio via hand held or portable radios, the penetration of portable internet connected devices is also crucial to look at. The implications for radio are two-fold. Internet connected 
devices such as smartphones or portable tablets provide the challenge of media competition as potential radio audiences may choose internet media over radio listening. This connectivity also represents a new avenue of mobile promotion and interaction for radio through these devices and new apps.

In a study by Edison Research and Triton Digital, the trend-line representing the ownership of smartphones shows a rapid increase over the period of 2009 to early 2014 (see Table 5).

Table 5

Percentage of Americans who Own a Smartphone

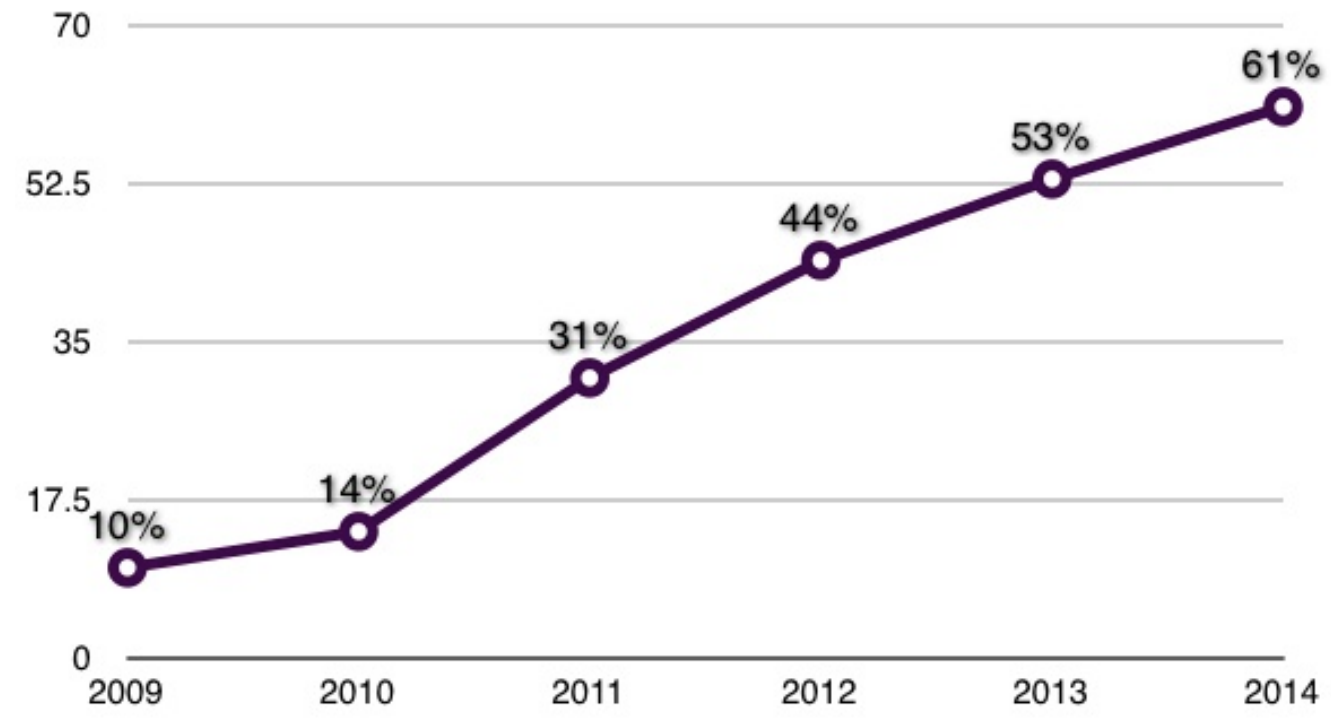

Source: Edison Research and Triton Digital. "The Infinite Dial 2014”. 2014. pdf. Over the past five years, ownership of smartphones has increased almost five hundred percent to an estimated 160 million American smartphone owners. This same study shows that nearly 75 percent of Americans under age 55 own 
smartphones, with those who are of the younger age groups showing the most smartphone ownership (see Table 6).

Table 6

Percentage of Smartphone Ownership by Age
- 18-24 Year Olds
. 25-54 Year Olds
- $55+$ Year Olds

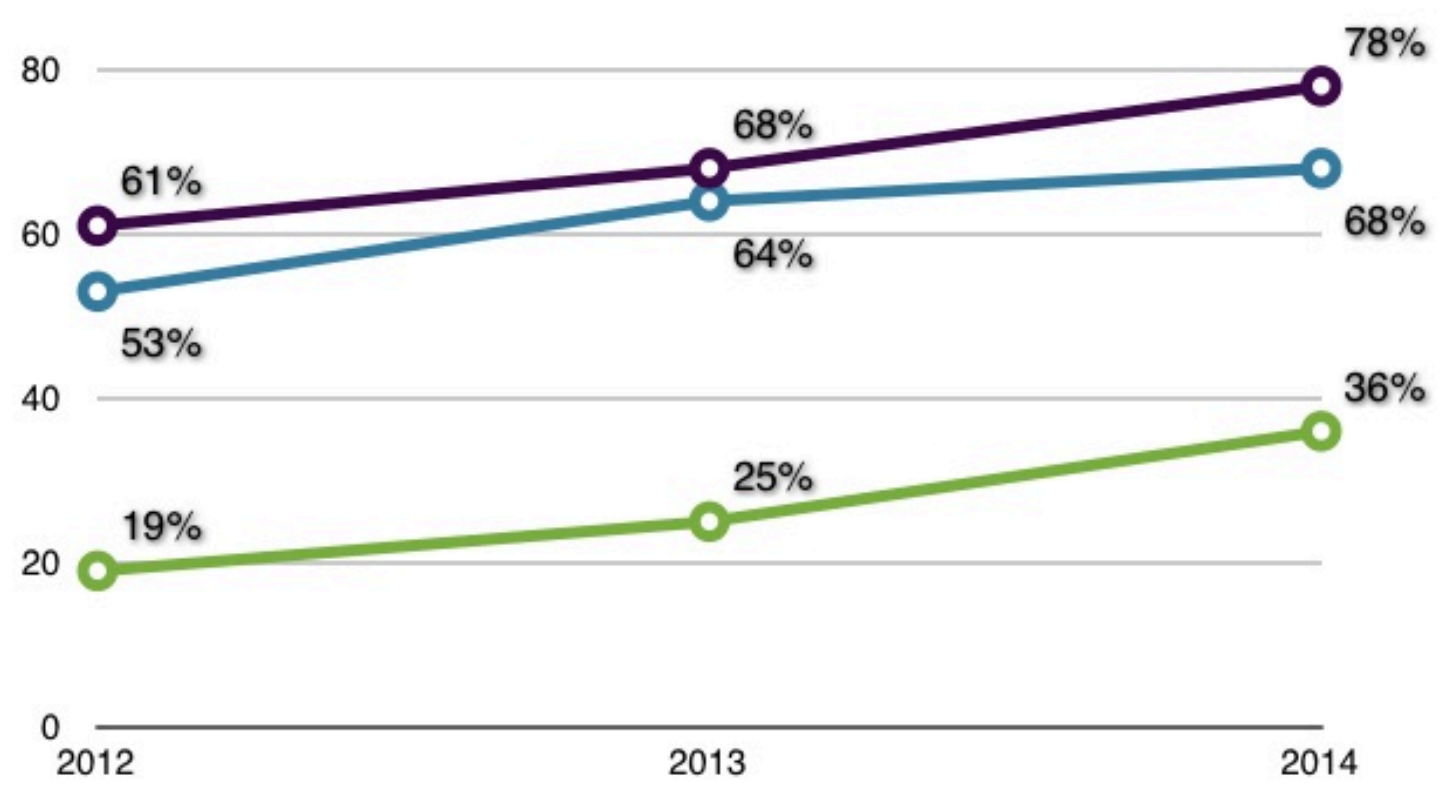

Source: Edison Research and Triton Digital. "The Infinite Dial 2014”. 2014. pdf. In the same study conducted by Edison Research and Triton Digital tracking the ownership of portable tablets, ownership nearly doubled during the period survey from 2012 to 2014 (see Table 7). 
Table 7

Percentage of Ownership of Tablets

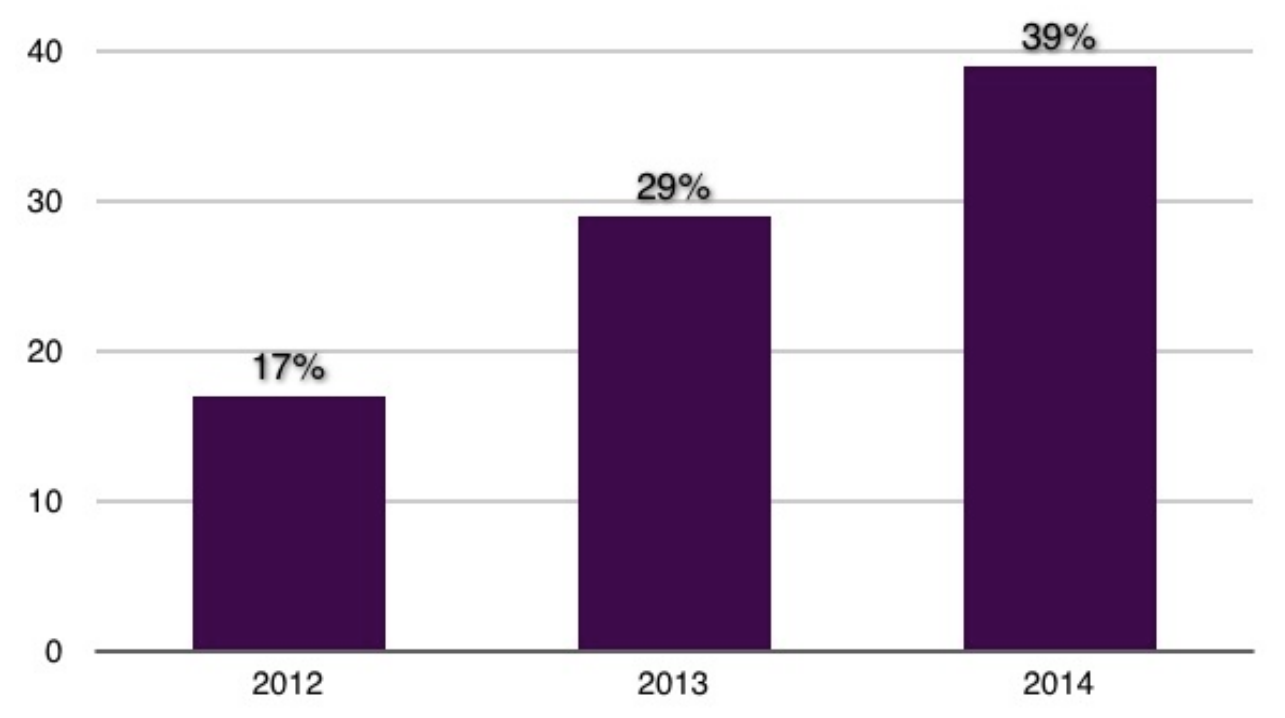

Source: Edison Research and Triton Digital. "The Infinite Dial 2014". 2014. pdf.

With all of the potential for internet connectivity via portable devices, how people are using the internet is another important consideration. The availability and portability of new media connected via the internet now provides a host of on line activities that people may now find to be vital to their every day lives. One important aspect new media now provides for individuals is the ability to communicate and maintain social relationships over the internet. The 2012 USC Annenberg School Center for the Digital Future report found that the majority younger adults considered the Internet and texting important or very important tools in maintaining social relationships, with the younger demographics valuing 
texting slightly higher in importance than the internet in maintaining social relationships (see Table 8).

Table 8

Importance of Internet and Texting for Maintaining Social Relationships for Young Adults by Age

$<19$ Internet

25 - 45 Internet

19 - 24 Internet

$19-24$ Texting

80

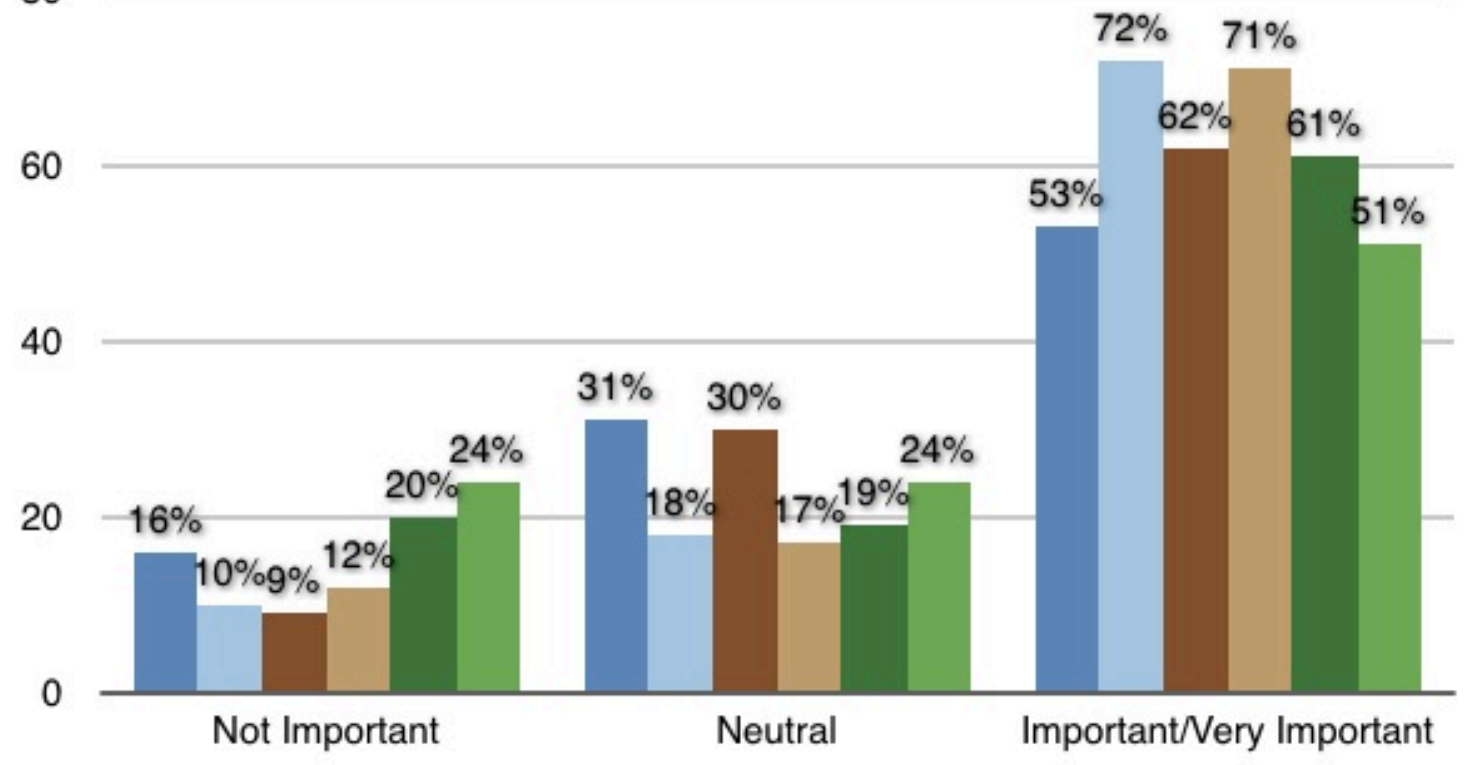

Source: University of Southern California. “The 2013 Digital Future Report USC Annenberg School Center for the Digital Future. 2013. pdf.

As Americans are now finding the Internet an important tool for maintaining social relationships, social media then becomes an area of interest. The Edison Research and Triton Digital study included a look at individuals uses of social networking sites. The study found that while the use of Facebook 
remains overwhelmingly strong, it may be leveling off in use having possibly reached its' saturation point. The picture and video sharing sites such as Instagram, Pinterest, Snapchat and Vine show the most growth over the survey period of 2013 and 2014 (see Table 9)

Table 9

Persons Age 12+ who have a Social Networking Site

2013

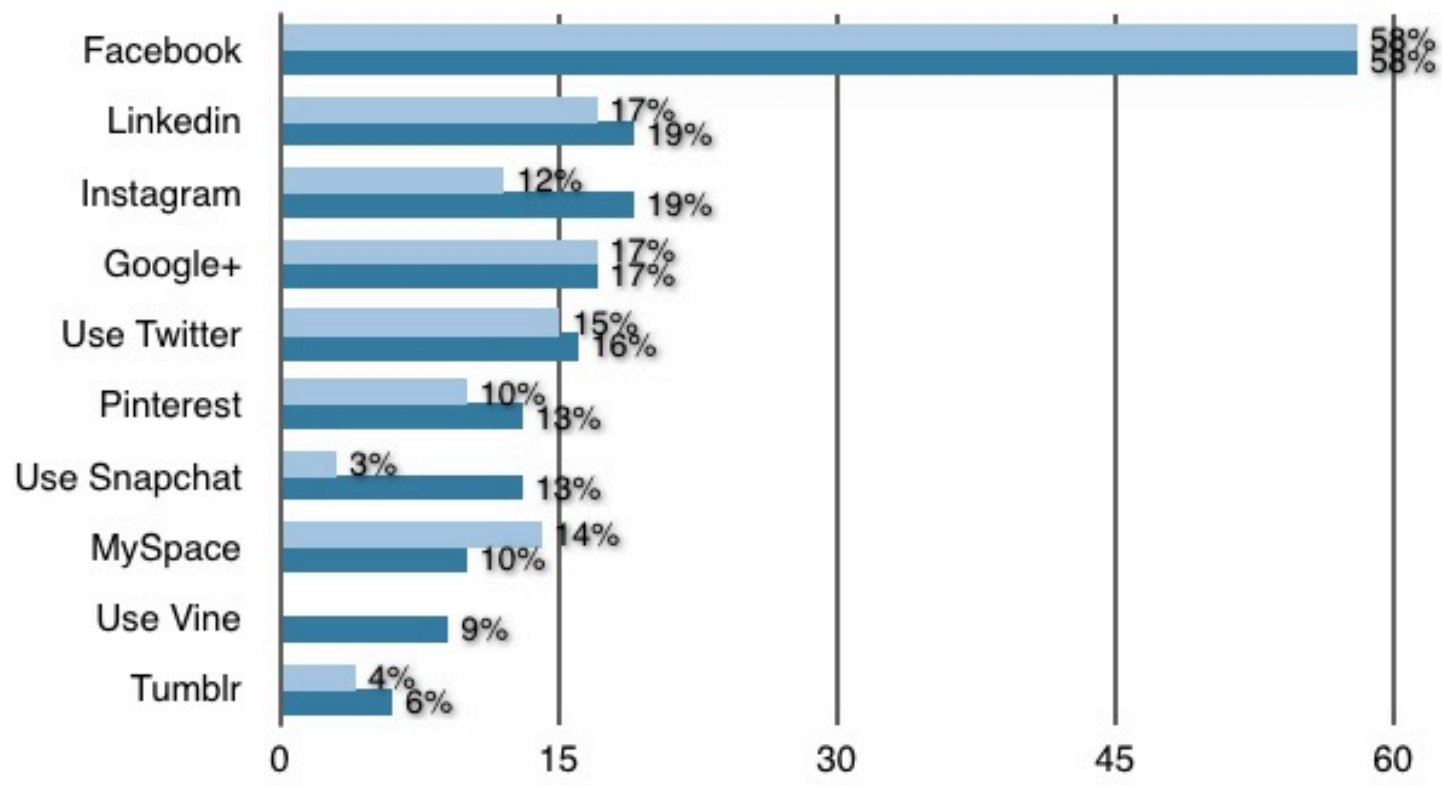

Source: Edison Research and Triton Digital. "The Infinite Dial 2014”. 2014. pdf. A study by Piper Jaffray reported in the Huffington Post hints at a clue for the leveling off of Facebook use. This survey detected a preference in use by Instagram by teen users over Facebook (Bosker). (See Table 10) 
Table 10

Most Important Social Networking Sites for Teens

- Facebook ○ Twitter $\circ$ Instagram $\circ$ Google+ $\circ$ Tumblr $\circ$ Pinterest o Other

50
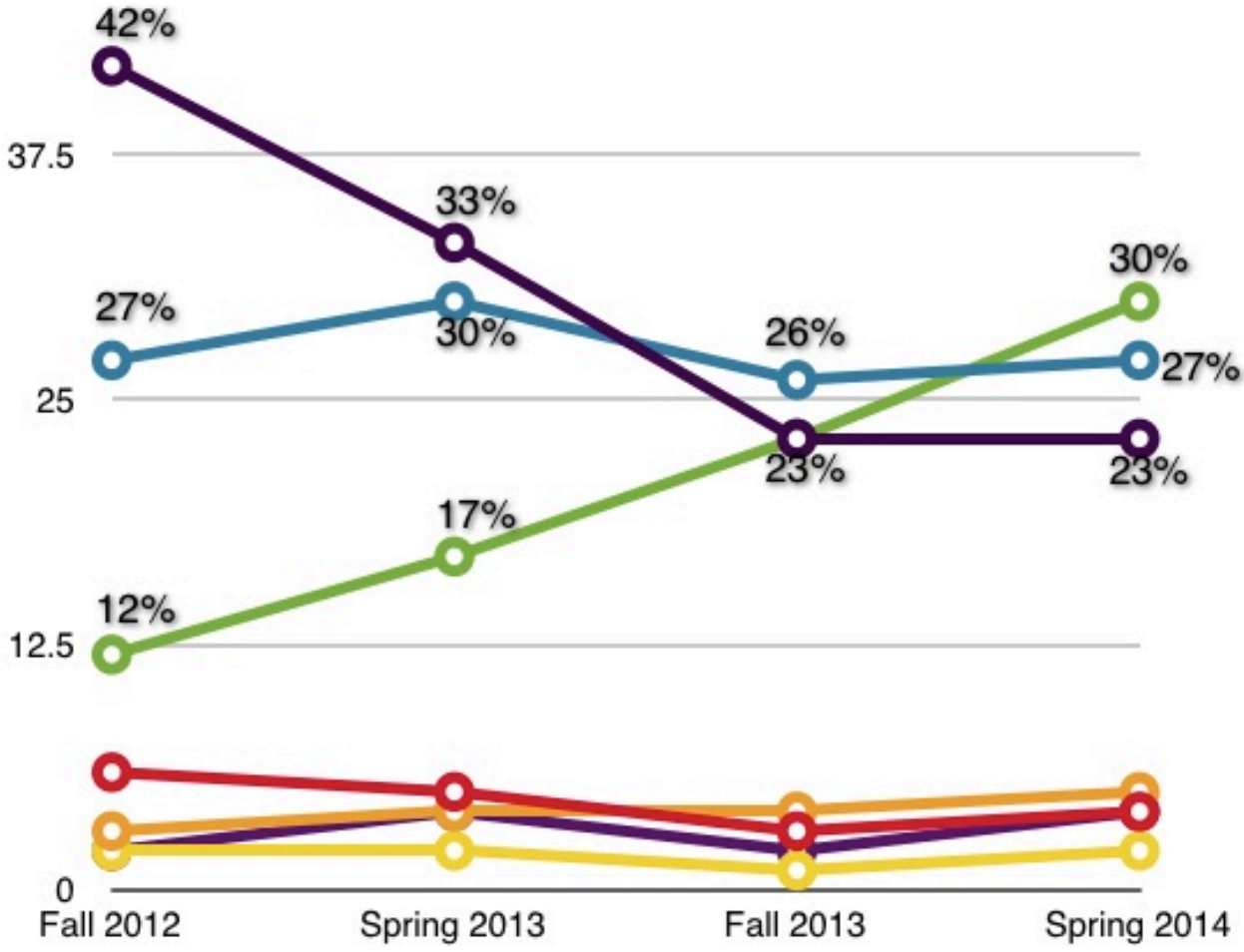

Source: Huffington Post. "Teens are Leaving Facebook for Facebook". 2014 Web.

A challenge for radio stations that target young adults will be in keeping up with new trends in the use of social media by their audiences, particularly teen audiences, who seem to be the trendsetters in uses of social media sites. 
The use of social media sites by radio audiences provides a conduit for promoting radio stations off air. The use of music sites by radio stations in the form of Clear Channel Music and Entertainments' iHeart Radio and CBS Radios' Radio.com provide online avenues for broadcasters to distribute and stream their content. The are also a number of other online music services that are competing for audience as well. The data reported in "The Infinite Dial 2014" by Edison Research and Triton Digital show that online music competition is intensifying as many music sites have significant levels of awareness among users (See Table 11)

Table 11

Persons 12+ Awareness of on line music sites

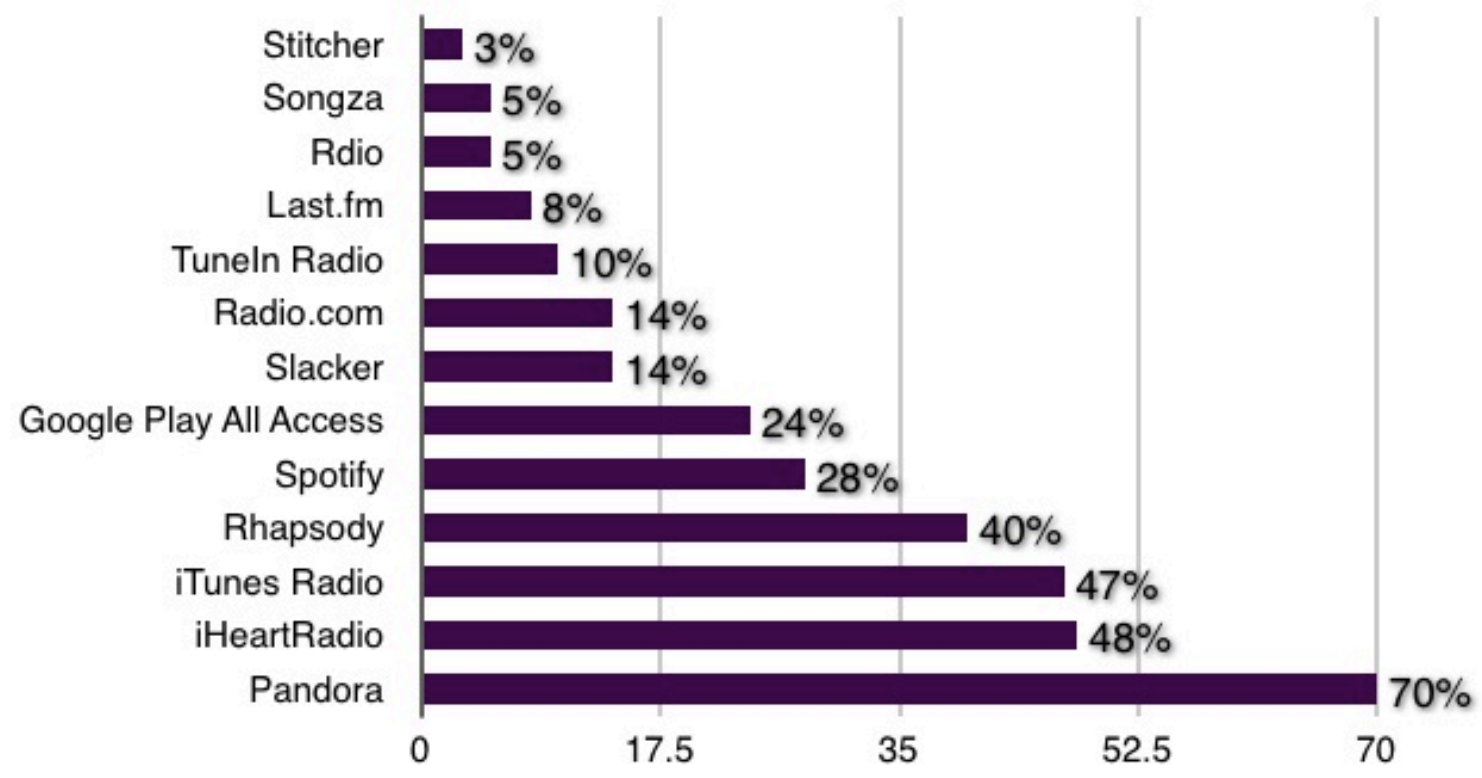
pdf.

Source: Edison Research and Triton Digital. "The Infinite Dial 2014”. 2014. 
The landscape of online sources for music is becoming increasingly crowded and the public is aware of many of the popular brands. For younger persons the most popular online sources for music are Pandora, iTunes Radio, and Spotify, and all age groups show a distinct preference for Pandora (See Table 12).

Table 12

Percent Who Listened to On Line Music Sites by Age

12 - 24 Last Month

25 - 54 Last Week
12 - 24 Last Week

$55+$ Last Month
25 - 54 Last Month

$55+$ Last Week

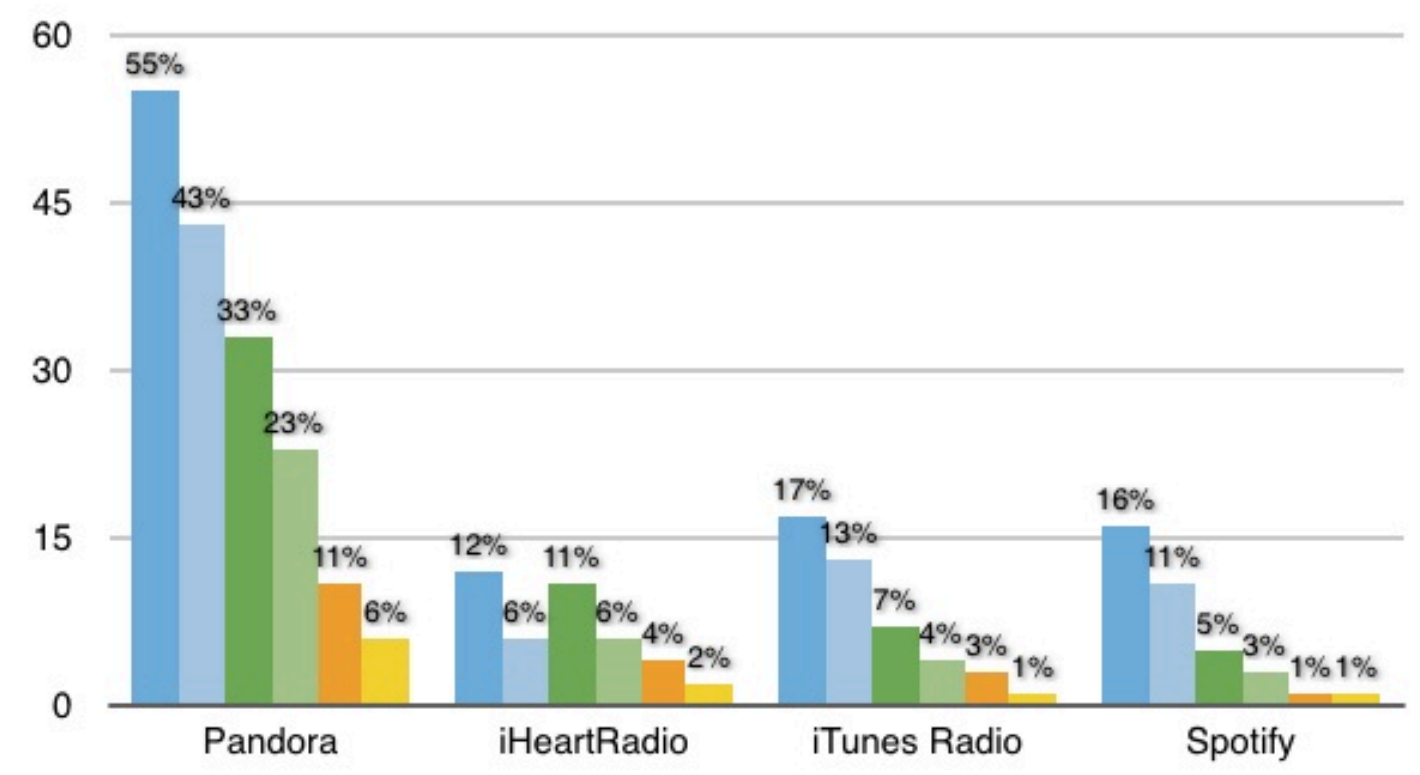

Source: Edison Research and Triton Digital. “The Infinite Dial 2014”. 2014. pdf. This same study also found that 81 percent of young adults age 12 through 24 watch YouTube for music videos or to listen to music, as opposed to 55 percent of the total population studied. 
Clearly, audiences have found uses for the internet in the form of connecting to people via social media, listening to music and for entertainment. In the meantime, AM and FM radio listening has remained strong as nearly 93 percent of Americans report listening to radio at least once a week, with persons 25 through 34 reporting averages slightly higher (Arbitron). Radio revenues also remain strong, reporting revenues for 2013 close to 18 billions dollars (Radio Advertising Bureau). (See Table 13)

Table 13

Radio Revenue, in Billions

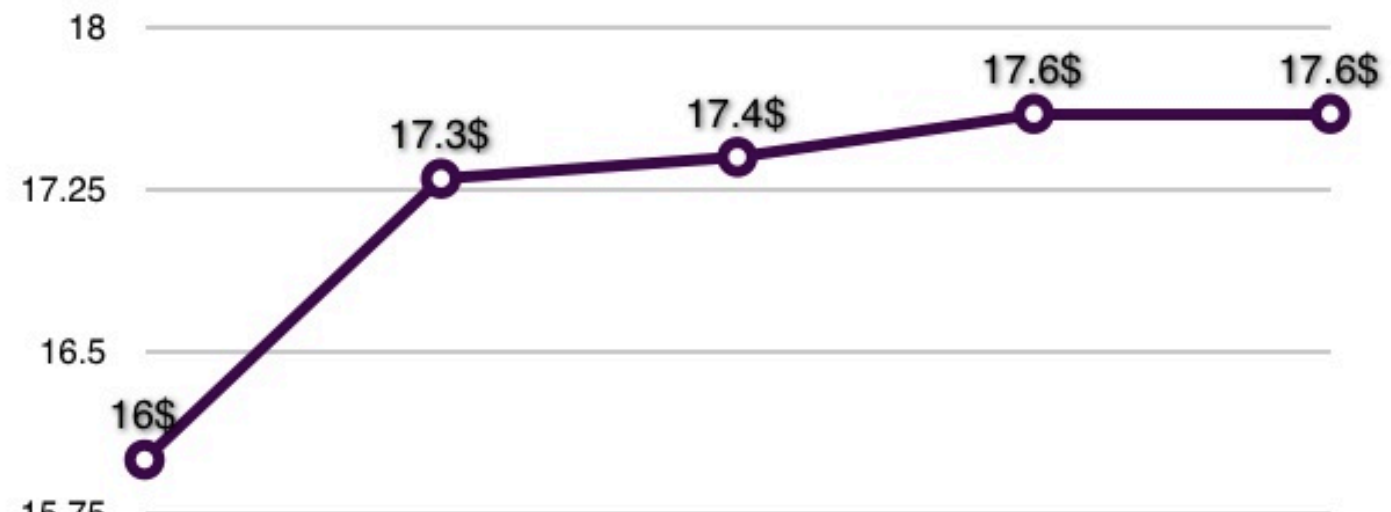

15.75

$\begin{array}{lllll}15 & 2010 & 2011 & 2012 & 2013\end{array}$

(Source: Radio Advertising Bureau. "Annual Radio Revenue Trends”. 2014. Web.)

While the use of the internet is growing, radio listening and the business of radio remains strong. It appears that the growing use of the internet may not be 
affecting radio listening and radio revenues adversely. Earlier academic studies inferring young adults preferences for $\mathrm{mp} 3$ players and sources other than radio for listening to music as adversely affecting radio listening may not be happening.

Somehow radio has remained robust in an environment where audiences are now used to multiple sources of music in the form of YouTube and on line music delivery applications and competition for the attention of the public in the various forms of social media. The adoption in use of new media and social media by the public may not be adversely affecting uses of radio. It might be possible that radio has overcome an earlier trend of the broadcasters late adoption of web tools for promotion, to actually incorporating web tools as part of the programming and promotion of radio stations, resulting in a new viability for radio broadcasting. 


\section{Chapter Three: Methodology}

The task of elucidating an answer to the question, the challenges and opportunities for radio programmers in maintaining and cultivating young adult audiences in the current media environment, is a large one. In order to keep this particular research to a manageable size, it has been decided to limit the research to radio stations that target young adults in a local market readily available to the researcher. This research is designed as a preliminary step in trying to understand the challenges and opportunities faced by radio stations, their programmers, and promotion and marketing persons. Further research in other markets, regions and countries would be necessary to definitively answer this question.

The radio market chosen for this research is the San Francisco area market. This is the fourth largest Nielsen rated radio market in the United States(All Access). The population covered by the Nielsen area is just over $6,370,000$ people consisting of a reported ethnic make up of 7 percent AfricanAmerican audience and 23 percent Hispanic audience.

The Nielsen survey period chosen for this research was the most recent publicly available survey at the time of this writing, the March 17th, 2014 ratings period. It was chosen to focus on the top rated radio stations in the 18 to 34 age demographic for this research. This is one of the most accepted young adult targeted age demographics by Nielsen. The top stations reported in this survey 
period, in this demographic, were chosen as they were showing success at reaching their audiences. Other stations in this market that target young adults, but did not rank in the top tier in the Nielsen survey, were not chosen for this research as they could not only suffer from the challenges of programming to young adults, but they could also suffer from other challenges including lower power, inferior transmitting location or local topography which may inhibit these stations from broadcasting to the entire survey area. For these reasons, stations that did not rank in the top of the 18 to 34 age demo for this survey were ignored. During the writing for this research Univision Spanish Top 40 stations KVVF and KVVZ debuted, and accurate survey data for these stations were not available. Follow up research of stations that fall outside the top ranked stations in this demographic may be of some interest for future research.

According to publicly available Nielsen data for the survey period chosen, the top ranked radio stations in the 18 to 34 demographic in the survey area were KMEL-FM, KYLD-FM, KMVQ-FM, KISQ-FM, KIOI-FM and KRZZ-FM. KMEL and KYLD formats are listed by Nielsen as Top 40/Rhythmic, KMVQ is listed as Top 40/Mainstream, KISQ is Rhythmic Adult Contemporary, $\mathrm{KIOI}$ is Hot Adult Contemporary and KRZZ is Mexican Regional. KMEL, KYLD, KISQ and KIOI are owned by Clear Channel Media and Entertainment, KMVQ is owned by CBS Radio and KRZZ is owned by Spanish Broadcasting System. All stations are located in San Francisco, with the exception of KRZZ which is located in San Jose. These six stations were chosen for this research. 
This research will utilize both quantitative and qualitative methodologies. Quantitative data will be collected by investigating these select radio station's websites. Qualitative data will be gathered through interviews of selected professionals at these stations in the field of radio programming and promotions and marketing.

A quantitative investigation of these radio station websites was undertaken to ascertain the on-line tools these radio stations are using to reach and engage their young adult audiences. This investigation is only directed at tools intended for the listener's benefit and use. These tools must exist for the use of promoting the station to listeners through on-line interactivity and not for the sole purpose of advertising, although advertising may be imbedded in some of these tools. Tools such as links, email and correspondence intended for business aspects, such as advertising and use by advertisers will not be considered. Station web links to email, blogs and social media would be examples of interactive tools available to listeners on the station website. On-line audio and video media players, podcasts, streaming players, mobile applications and RSS feeds would also be included.

The researcher visited these radio station's websites and listed the online tools found on their websites. These on-line tools are listed on Table 14 in order to discover how these stations are utilizing these tools to interact with their listeners. The investigation of these websites was conducted on May 2, 2014. 
The researcher interviewed Program Directors and Promotion and Marketing Directors representing all of the aforementioned stations in order to gather qualitative data. The interviews were conducted either by telephone or in person at the discretion of the interviewee. Interviewees were asked the same set of questions; however, follow up questions may have differed depending on the nature of the interview conversation. All interviews were recorded and transcribed and offered to the interviewee for amendment and approval. Transcriptions of the interviews were coded and categorized for similar emerging themes and content. Due to proprietary concerns of the interviewees, stations, or the company the interviewees work for, anonymity of the respondents was guaranteed. The interviews were conducted between April 3 and April 24, 2014. The interview protocol included questions relating to the target audiences of the radio stations identifying information about the age, gender, education, income, lifestyle interests such as entertainment activities, family size and familial obligations of this target audience.

The questions were designed to have the interviewees respond to their on air strategies employed by stations to reach their audiences, online strategies the stations use as a way to reach and engage listeners, off the air or street promotions the stations use to reach and engage listeners and other marketing strategies the stations use to reach and engage audience. Interviewees were also asked their impressions of challenges faced by new media, traditional media 
and competing radio stations. Interviewees were asked about their general impressions of challenges faced by their respective stations. 


\section{Chapter Four: Results}

"....in a dialogue it may be said that the two people are making something in common, i.e., creating something new together." David Bohm (Bohm)

A survey of the top six, 18 to 34 year old demographic performing radio stations in the San Francisco radio market during the March 17th 2014 Nielsen rating period was undertaken. Research was gathered by visiting station websites and by interviewing representatives of the stations. This chapter is a reveal of the data collected from the quantitative and qualitative surveys done in this research. A more detailed discussion of the implications of the research will be contained in a following chapter. However, a cursory look at the data in this chapter shows that, at least the stations involved in this survey are reaching out to, and trying to connect with potential audience in new ways not possible before the dawn of the digital landscape.

Part One, Quantitative Research

The survey of six radio station websites that had success with 18 to 34 year old listeners in the San Francisco radio market during the March 17th 2014 Nielsen rating period reveals a trend toward very robust content presentation. Although this was just a small sample of radio station websites, and a larger 
sampling may be needed to confirm this trend, the earlier indication that FM radio station websites were underperforming in the content analysis by Potter seems to have been reversed (Potter 381). The results of this analysis are included in Table 14.

The San Francisco website analysis reveals that all stations surveyed had developed multi-platformed applications which audience members can use to listen to stations on a variety of smartphones, tablets, home computers, and entertainment systems such as Xbox and Amazon Fire TV, and multiple manufacturers of in car radio and audio systems.

All stations surveyed also included a capability to live stream the radio station directly from the website. All stations surveyed supported curated music channels where listeners could select music featured on the stations for inclusion in a listener designed playlist or music channel.

All stations surveyed allowed for interaction via email, Facebook, and Twitter. All stations surveyed also allowed for web users to receive real time updates from the radio stations via RSS feeds.

All stations surveyed featured blogs where website visitors could read news, lifestyle, entertainment, and celebrity content. Most stations also featured individualized blogs authored by the on air personalities. All stations also included multiple uses of video.

All stations surveyed also used the AddThis feature. AddThis allows users of the radio station websites to bookmark content via almost three hundred 
different web services such as Pinterest, Facebook, and Instagram (AddThis). This feature allows website visitors to customize the way they interact with the web content, while providing the website publishers valuable data about website visitors.

Most stations had links for interaction on social media sites Google+ and Instagram, as well as links to the station's YouTube channel.

Stations that are owned by Clear Channel Media and Entertainment, which includes four out of the six websites surveyed, have many of the same features and also look similar in layout and design. The Clear Channel websites for $\mathrm{KIOI}, \mathrm{KISQ}, \mathrm{KMEL}$ and KYLD included a way for website visitors to buy songs from the station's playlists. This was accomplished by providing a link to iTunes for each popular song where website visitors could download the song and album.

Half of the websites surveyed use Pinterest, although all of the websites surveyed allowed for website visitors to bookmark content to Pinterest via AddThis. The AddThis bookmark capability was also true for social sites Digg, Foursquare, Line, and MySpace. These sites appeared in less than half of the radio station websites surveyed.

A few features on the websites surveyed were unique to a particular station. The website for Spanish language radio station KRZZ-FM featured a live chat room with the on air personality and links for text messaging the personalities directly. The website for CBS Radio broadcaster KMVQ-FM 
featured a live video webcast of the morning show, podcasts featuring the morning show, and a feature that allowed website visitors to download a cell phone ringtone of their favorite music played on the radio station.

These websites allowed for multiple opportunities for website visitors to interact with the radio stations through the social media imbedded in these websites. There seemed to be many ways for website visitors to leave comments and feedback, and to share website content with their friends via social media. This capability allows an avenue of promotion of the radio station separate to the on air broadcast. It also allows the radio station an online presence, on the very social media where potential audience members are spending time.

The inclusion of blogs, curated channels, videos, live streams, podcasts, and webcasts also provide website visitors entertainment value. Web content also provides visitors an opportunity to spend time with the radio station via the website. This allows important branding opportunities for the radio stations (see Table 14) 
Table 14

Website Digital Media Tools of Successful San Francisco Area Radio Stations in 18-34 year old Demographics

\begin{tabular}{|c|c|c|c|c|c|c|}
\hline & $\begin{array}{c}\text { KIOI-FM } \\
\text { Star } 101.3\end{array}$ & $\begin{array}{c}\text { KISQ-FM } \\
\text { Kiss FM }\end{array}$ & KMEL-FM & $\begin{array}{c}\text { KMVQ-FM } \\
\text { Now } 99.7\end{array}$ & $\begin{array}{l}\text { KRZZ-FM } \\
\text { La Raza }\end{array}$ & $\begin{array}{l}\text { KYLD-FM } \\
\text { Wild } 94.9\end{array}$ \\
\hline AddThis & & & & & & \\
\hline Apps & & & & & & \\
\hline Blog & & & & & & \\
\hline Chat Room & & & & & & \\
\hline $\begin{array}{l}\text { Curated } \\
\text { Channel }\end{array}$ & & & & & & \\
\hline Digg & & & & & & \\
\hline Email & & & & & & \\
\hline Facebook & & & & & & \\
\hline $\begin{array}{l}\text { Four } \\
\text { square }\end{array}$ & & & & & & \\
\hline Google+ & & & & & & \\
\hline Instagram & & & & & & \\
\hline iTunes & & & & & & \\
\hline
\end{tabular}




\begin{tabular}{|c|c|c|c|c|c|c|}
\hline & $\begin{array}{c}\text { KIOI-FM } \\
\text { Star 101.3 }\end{array}$ & $\begin{array}{l}\text { KISQ-FM } \\
\text { Kiss FM }\end{array}$ & KMEL-FM & $\begin{array}{l}\text { KMVQ-FM } \\
\text { Now } 99.7\end{array}$ & $\begin{array}{c}\text { KRZZ-FM } \\
\text { La Raza }\end{array}$ & $\begin{array}{l}\text { KYLD-FM } \\
\text { Wild } 94.9\end{array}$ \\
\hline Line & $N$ & & & & & \\
\hline $\begin{array}{l}\text { Live } \\
\text { Stream }\end{array}$ & 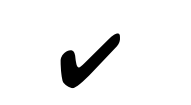 & $\nu$ & $V$ & $\nu$ & $\nu$ & $V$ \\
\hline $\begin{array}{c}\text { Live } \\
\text { Webcast }\end{array}$ & & & & $\nu$ & & \\
\hline MySpace & $\mu$ & & $\mu$ & & & \\
\hline Pinterest & 1 & $\nu$ & & & & $\nu$ \\
\hline Podcasts & & & & 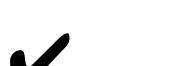 & & \\
\hline $\begin{array}{l}\text { Ringtone } \\
\text { Matcher }\end{array}$ & & & & $\nu$ & & \\
\hline RSS Feed & 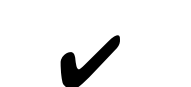 & $\mathcal{V}$ & $V$ & $\mathcal{V}$ & $v$ & $\nu$ \\
\hline $\begin{array}{c}\text { Text } \\
\text { Messaging }\end{array}$ & & & & & $\mathcal{N}$ & \\
\hline Twitter & $\nu$ & $\nu$ & $V$ & $\nu$ & $\nu$ & $\nu$ \\
\hline Videos & 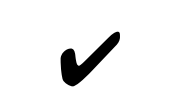 & $\nu$ & $\nu$ & $\nu$ & $\nu$ & $\nu$ \\
\hline Youtube & $\nu$ & & $\nu$ & & $\nu$ & $\nu$ \\
\hline
\end{tabular}

(Source: 99.7 NOW. "99.7 [NOW!] All the Hits, Pop News, Artists, Celebrities."

Web. 2014, KISS-FM San Francisco. “98.1 KISS-FM San Francisco Bay’s Old

School!. Web. 2014, KMEL-FM San Francisco. “106 KMEL San Francisco’s

Home for Hip Hop and R\&B!. Web. 2014, LA RAZA San Francisco. "93.3 FM LA 
RAZA San Francisco. Web. 2014, Star 101.3 San Francisco. "Star 101.3 San Francisco's Variety from the 90's, 2000's and Today!. Web. 2014, WILD 94.9. “Wild 94.9 The Bay’s \#1 Hit Music Station!. Web. 2014.)

Part Two, Qualitative Research

Representatives of all six stations were interviewed using the same set of questions. While all stations named other radio stations as main competitors, the core challenges these stations face, as identified by their representatives, is more focused on what these stations need to do to maintain the attention of potential listeners. The respondents to these interviews all mentioned that the digital space is growing so much, and that people have many choices beyond radio now. People can listen to music anytime they want, on demand. They can have their own custom curated channels on iHeart, Pandora, or Spotify. The challenge for radio programmers and marketing and promotion people is how to break through the cluttered digital space. Moreover, radio professionals are tasked with trying to make their stations a favored choice for potential audiences amidst this digital clutter.

All respondents identified the key to success in breaking through the clutter as being more than just music. Station representatives expressed that content regarding listeners lifestyles, interests, and families as being key avenues of connection between stations and their audiences. They point out that 
radio offers personalities who connect with audiences. One respondent remarked that people have the choice to listen to music on their phone, iPod, or a curated channel, but hopefully the listener would rather choose that station's morning show because the personalities there were going to talk about something that happened recently or that there would be a funny story, or crazy topic that would give the listener the feeling that they are connected to the station in some way. All respondents stressed that radio programming had to be engaging in some way, more that just playing a list of songs.

Another way stations felt they could meet the challenge of breaking through and engaging audiences was by having a connection to the local community. As an example, one broadcaster mentioned the 'Batkid' story (SF Gate). On Friday November 15, 2013, a strange signal was flashed onto the side of the Hyatt Grand Regency Hotel in Downtown San Francisco. This signal was a desperate call for Batkid to come and save the day. Miles Scott, a five year old cancer survivor, asked to be a superhero for his Make-A-Wish foundation wish (Collman and Warren). Batkid's exploits had him riding in a Batmobile, rescuing Lou Seal the mascot of the San Francisco Giants, receiving the key to the city from the Mayor, and even garnering the attention of President Obama. San Francisco media covered this story extensively, including San Francisco radio stations. Respondents to this research mentioned the Batkid phenomenon as one type of community event that helped radio connect with the local community. Stations featured live on air reports and reported the event on their websites 
(Manuel). Respondents to this research pointed to the on air reports along with even more coverage of this event on their websites as an example of the radio station using the tools available to connect with community.

Station websites also allow for in depth reporting and interviewing. Respondents reported on the change in how artists interviews are conducted. Stations can do a brief five to ten minute on air interview with an artist, but also conduct a longer 20 or 30 minute video interview with the artist and post it to the station website. Many respondents pointed to this feature of allowing for longer interviews on station websites as a both a positive branding opportunity and another way to connect with the interests of potential listeners. As an example, a respondent mentioned that a person's web search for a video by the artist "Future" could lead that person to the station's website featuring the extended interview of the artist conducted by the station, thus drawing a new individual to the website and potentially introducing and linking that person to the station's brand.

In addressing the issue of challenges stations face, respondents raised some interesting points. Respondents remarked the digital space is growing so fast and consequently people's use of digital tools are changing, the challenge for radio is to respond quickly to both the new digital tools and changes in behaviors regarding the use of the digital space. Respondents all stated that they were using new media tools extensively to reach potential audiences. One respondent stated that earlier on in the development of websites and the internet, 
many broadcasters did not know the potential for these media tools. This respondent felt that many radio broadcasters viewed new media tools as a threat at that time. This respondent felt that broadcasters now understand the benefits of new media tools in marketing and promoting radio and that the broadcaster must now embrace these opportunities and maximize them whenever they can. Identifying and adjusting to these challenges early was cited as key in maintaining listener interest. One of the radio stations surveyed uses "Now" as their marketing brand. This respondent remarked that the pressure to stay up with and ahead of current trends is acute, particularly when taking the station's branding into account.

It was suggested that the general market listeners were quicker to adopt the digital space than Spanish speaking radio listeners. This did not mean that Spanish language stations were slower in adopting new technologies. The perceived slower adoption by these listeners allows for these technologies to be in place at the station website and available for use by potential listeners at the time when the audience will need or want them.

Even with the availability of Pandora, Spotify, and YouTube, these radio station representatives felt that their listeners found out about new music through listening to the radio, whether it was their station or a competitors. Introducing listeners to new music has been an important function of music programmed stations. Respondents communicated the need for stations to stay up on new music trends so as to introduce music to their listeners. 
One respondent remarked that the digital challenge was different for listeners over the age of 30 . The comment was that many listeners under the age of 30 have never known a time when these digital tools did not exist. Radio is just part of the palette of media choices along with Pandora, YouTube, and the like for these under 30 listeners. The real challenge was for listeners over 30 years old, this respondent felt. These older listeners view new technologies as the "shiny new things", and therefore radio was "uncool" for these older listeners. Older listeners may be listening to FM radio broadcasts simulcast on iHeart or Sirius/XM, but their perceptions may be that they are listening to content that was originated only on the internet or satellite radio and not from a terrestrial broadcast. It is "cool" for these older listeners to listen on these new technologies, while they may be unaware that they are in fact listening to an "uncool" radio broadcast.

The challenge, in this case, is twofold. Getting the younger listener to choose radio as part of a media diet, and getting the older listener to see that radio listening is not "uncool". All of the radio representatives interviewed responded that their stations performed significant outreach to teenage listeners. It was important to these respondents that they get teen listeners "in the tent" so that by the time they reached older ages, their radio listening habits will be formed. All of the respondents felt they are reasonably successful in cultivating young listeners and forming their listening habits. The success of changing older listeners perceptions of radio from "uncool" status remained more obscured for 
the respondents. They reported having reasonable success with many forms of outreach and promotion, however the current image of radio in these older listeners persist.

All respondents surveyed have integrated new media tools into their radio promotions. All respondents reported having off air contesting. Listeners who only listen to the on air broadcasts might be completely unaware of some of these types of promotions. Respondents identified Twitter, Facebook, and Instagram as platforms for some of these promotions. All of these stations look at social media as a big benefit to their core business. These benefits include the ability of social media to reach vast amounts of people than other traditional forms of promotion. Every respondent remarked on the potential of a video, picture, or post on the station's website to go viral via social media.

These social media tools also allow another way for radio stations to quantify a measure of success. Figures on how many page views, likes, shares, re-tweets a station gets are now a new and valuable metric for these stations. This new data is noted by the stations in addition to the traditional metrics of Nielsen's PPM measurements or independent market research conducted by broadcasters or third parties.

Social media was viewed as very important to these stations when they are mass mediums. Social media that is positioned as mass, such as Facebook, Twitter, and Instagram are obviously important as they reach mass amounts of people. Social media that are a little more niched are not as successful for 
stations as users of those media were thought of as being "anti-mass media" or "eclectic".

Respondents also feel that social media is a valuable tool because of cost, it is free to open an account. In a business climate where some stations cannot afford television advertising or outdoor advertising, social media is viewed as an extremely good promotional value. Social media can also integrate into traditional forms of promotion such as on air, street, on line, and text to provide what one respondent termed an "all around" or "360 approach" to promotions.

Two respondents also remarked on the importance of the program Shazam is to radio programmers. Shazam is an app that allows users to identify music as well as offering users curated music channels (Shazam). Users can hold their smartphone or tablet up to a speaker or headphone playing music and the app will attempt to identify the song for that user. The app also collects valuable data for business partners who subscribe to Shazam. Record companies can spot trending songs, in real time, and get regionalized data (Kopper). Shazam's representatives state that the service can typically predict the songs that will top the Billboard Hot 100 chart 33 days in advance. Shazam predicted the meteoric rise of Daft Punk's "Get Lucky" to be the top song of the 2013 summer (Lopez). Shazam data is currently a valuable tool for radio programmers in most of the radio stations who participated in this research. New media tools are essential in promoting stations to audiences, promoting music to audiences, and keeping radio up to date with listeners preferences in music. 
Another new media tool, web streaming, also provides the traditional broadcaster an opportunity to broadcast more radio channels. One such example is Clear Channel Music and Entertainment's LGBT channel which targets broadcasts to the Lesbian, Gay, Bisexual and Transgender community. As a traditional broadcast channel, the content may not be successful over a single terrestrial radio station or radio network. However, when broadcast on the internet over Clear Channel's iHeart platform, the channel now has a world wide reach. This reality makes many eclectic and niche programming economically viable. This is particularly attractive to a mainstream broadcaster like Clear Channel which can call on the company's vast resources for content, promotion, and distribution.

This also allows Clear Channel to use different business models. In the case of the LGBT Channel a sponsorship model is employed rather than the traditional terrestrial radio spot commercial approach. Segments are sponsored by advertisers and presented with fewer commercials. The representatives of Clear Channel state that the company and their employees are specifically focused on building iHeart radio into a multi-function app that has everything that listeners want and is everywhere listeners want it to be, on multiple platforms.

Respondents reported another benefit of on line streaming was the ability to stream the broadcast signal on station websites. This allowed stations a presence in the digital space. It also allows stations the ability to enhance 
revenue through commercial replacement, the ability to run alternative advertising on the streams of the stations.

All respondents reported that contesting was a very important promotional activity. All remarked on contests such as cash giveaways, musical performance and concert tickets, and tickets to theme parks, both locally at Six Flags and Great America, and to Anaheim California's Disneyland as prizes that are popular with listeners. Most of the station's representatives also commented on the importance of concerts or music events promoted primarily by the stations themselves. Known as "listener concerts" or "listener parties", the radio station is the primary concert promoter at these events. In smaller venues the station can book a club or theater for an intimate show for listeners. In larger venues, stations will host a number of acts in a day long festival. Since the act or acts are booked through the station and not through a concert promotion firm, this allows the station to keep ticket prices low and provides the station more control over the promotion. The large listener concert is seen as a good value to listeners over a standard concert presented by a concert promotion firm. When concerts are promoted through a concert promotion firm, there are usually one headliner and one or two opening acts. In the radio station promoted listener concert, there may be eight or more acts with some other acts appearing on side stages as well. Respondents felt that the listener concert model presented a better music value to their listeners, while vigorously reinforcing the stations brand image. 
One respondent remarked on the importance of providing the listeners with a unique and unforgettable experience through the station's promotions. One example of this type of promotion was a "Bowling with Wiz Khalifa" promotion. Listeners won the chance to meet the artist Wiz Khalifa, and to bowl with him. This also allowed listeners to get their pictures taken with the artist which naturally, gets shared over and over again on social media providing even more promotion for the station. Some stations surveyed also have a "VIP Lounge", or another dedicated space, where artists can do a meet and greet with listeners and clients. This also provides a similar benefit to the station in regards to station promotion. Radio station representatives feel that promotions of these types provide listeners with an experience that is not offered by any other media, and reinforces the need to listen to the radio station, or connect with it via social media, in order to win a chance to go to one of these unique events.

When asked about soliciting listener feedback, respondents remarked that the feedback channel is less one sided. One respondent stated "it used to be us to them". Listeners used to contact the station either by telephone or by coming out to an event. Now, every respondent listed Facebook as one of the effective tools for soliciting listener feedback. Websites and social media in general were mentioned as avenues for listener feedback. One respondent used the examples of the website, Facebook, and other social media as an example of how communications with listeners are getting less one sided and are now more twoway. Calling the radio station via the telephone is still done, however it was 
admitted by respondents that listeners may not get through. Street promotions are still a valuable way for listeners to connect with stations, and representatives of the Spanish speaking station emphasized the importance of street for their listeners. The app Shazam was mentioned as an avenue for listener feedback as was PPM and station initiated research.

Looking forward, some respondents remarked on changes coming to in car listening. The advent of the digital dash will replace the standard in-dash radio. Cars will be equipped with computers in the dash, with the car itself being being connected wirelessly to the internet and possibly also being a WiFi hot spot. This was seen as a potential for broadcasters to add more on line radio channels on which to broadcast niche programming to audiences. One respondent posited the demise of satellite broadcasts at that time, as listeners would have no need to subscribe to Sirius/XM and also pay for a satellite receiver when a variety of music channels, streaming audio, curated channels and traditional broadcasts would all be available in the digital dashboard.

A respondent questioned the internet business model of "freemium" service, where a startup content provider offers service for free. After a period of time the content provider begins to offer the service either with commercials for free or without commercials for a premium price. This is a change in business model that consumers may not like. In the example given by the respondent, consumers were happy with the service, but now they have to pay for the same service they once got for free. The respondent pointed out that the standard 
radio business model is well established and accepted. Listeners know that they are going to get radio programming for free for the price of listening to some commercials. Radio does not have to change the model of a station's core business going forward. At this time, Clear Channel Music and Entertainment does not have commercial advertising on the curated channels on iHeart. This might be because of the perceived negatives in introducing commercials to a once free service, and that Clear Channel's core businesses can support iHeart without commercials on the curated channels at this point. There are challenges going forward for businesses such as Pandora, which is now adopting advertising, much the same as when Sirius/XM added commercials to it's subscription service.

The quantitative and qualitative research provides enlightening examples of how radio stations are meeting the challenges and adapting to a new environment of digital space. Radio seems to be able to provide a connection with listeners within the conventional model of broadcasting, however these new tools offer additional avenues for radio broadcasters to connect with audiences. Contrary to earlier predictions of the internet being the beginning of the demise of traditional media, the internet and new media tools are key in sustaining and growing the traditional media. 


\section{Chapter Five}

Analysis of Data and Conclusions

"A new medium...never..leave(s)the old one in peace. It never ceases to oppress the older media until it finds new shapes and positions for them" Marshall McLuhan, Understanding Media (McLuhan 174)

The excitement over one boy's discovery of this unbelievable new medium was undeniable. A young Norman Corwin was astounded at the new technology available to him by which he could access the world. He would later recounted his astonishment: "Somebody on the block said..there's this thing called radio..a quaker oats box with coils of wire wrapped around it...and in came the world! I remember tuning in, I lived in Boston...oh my god, Schenectady New York! What a thrill that was!" Empire of the Air:The Men Who Made Radio (DVD)

Radio was the emerging technology of the early 20th century. Much in the way we marvel at the new technologies and applications available to us now in the early 21 st century that connect us to our world, Norman Corwin and his friends on his block were enamored with the new radio technology and the use of radio to connect to their world. The technology needed to build an early receiver was simple and for people who could not afford to buy a radio receiver, with a little instruction and some spare parts, they could build their own receiver. Excitement over radio grew quickly, and soon more affordable store-bought 
receivers were available to tune in the growing number of new radio stations that provided the content for the emerging mass audience.

Parallels between the emergence of radio then, and of today's new technologies are easy to draw. The devices and platforms which make up the infrastructure of our digital landscape seem to become more available and varied. Computers and tablets, smartphones, google glass, smart watches, the emerging digital dashboard in automobiles allow us to connect with our new world of through social media, on line audio and video, the availability of news and information, and more.

True to Dr. McLuhan's pronouncement, this new media was threatening to many in the old media at first. Many radio broadcasters were slow to adopt these new media tools. Today radio has embraced these tools and adapted to them in such a way as to reshape and reposition radio.

Successful radio practitioners have always known that radio can forge a connection with listeners. The emergence of new technologies has reconfirmed the need for this connection as stated by the radio programmers and promotions persons in this research. To make these connections, radio has to be more than just music. Radio formats do rely on playing large amounts of music, but programmers know that connections must be made between the performance on the radio and the radio audience. Radio morning shows are typically personality based, with a strong personality leading a show with a cast of characters who provide entertainment as well as traffic, news, and weather. Radio programmers 
in this research have pointed to the importance of the connections these radio performers must make with audiences as a way to make radio listening different and unique, as opposed to listening to a playlist, curated channel, or other music radio competitor.

While all the respondents in the research expressed the importance of on air talent in making connections with audiences, none offered strategies for developing talent, nor were they asked as part of this research. There are issues of concern for radio when it comes to talent development. With many air shifts in many stations voice tracked, the opportunity for in station promotion of air talent has decreased. Since radio consolidation and the introduction of tracking technology, stations that used to have live air talent 24 hours, 7 days a week, now may have live and local talent for only a few shifts. Some stations elect to have major shifts such as drive time shifts produced by out of market talent in a convention similar to standard syndication models. Other stations may voice track evening, overnight and weekend shows by part time employed announcers. The result of much of the currently adopted voice tracking technology is fewer radio announcers. The obvious reason for having fewer announcers is to cut costs on salaries. Since their are fewer announcers being employed in radio, and there are fewer live air shifts available, this decreases the ability for talent to be groomed for live and local air shifts respondents to this research pointed to as necessary for success in connection to audiences. Extrapolate this trend across medium and small market stations where 24 hour live programming has given 
way to syndicated or voice tracked programming, and the concern for talent development grows greater. The small and medium markets were known as places for talent development in years past. Now that small and medium markets have adopted voice tracking technology fewer opportunities exist for talent development.

Because of the changes in the radio business and technology of the recent past, the development of talent in station and across markets has lessened the pool of available talent. Radio needs to address these issues. Programmers may want to open up an evening air shift or weekend air shift at their stations to live talent as a means to develop staff in station. Ownership groups should be willing to consider their stations in medium and smaller markets as breeding grounds for talent development, with the smaller market stations feeding regional talent to the larger markets.

Radio programmers may know the ability of radio air talents to connect with audiences, and they may know the need for talent development. This proposed strategy for developing talent run counter to the accepted voice tracking and syndicated business model where higher productivity for less cost is demanded. However, until radio strikes a balance in of levels of productivity with the need for talent development, much of the benefit of personal connections made between air talent and listeners will not be realized. 
Programmers also know that in addition to playing music, and in addition to having entertaining and compelling talent, the station has to make connections with the community. In both on air content and off air promotional activities, radio's local tie in with the communities these stations serve is considered by the research gathered here to be crucial to the success in programming. This is another reason for radio programmers to have a robust live presence as opposed to voice tracked or syndicated content.

Respondents from both Spanish and English language stations pointed out different challenges for foreign language stations. One such difference is the lack of choices foreign language audiences have for radio in the United States. Respondents pointed to the many English language format choices available to radio listeners, and that foreign language radio formats had fewer narrowcasted formats than their English formatted counterparts. The perceived reason for this difference in programming was that there are more English speaking stations, and more competition in the English market, hence the need for narrower and narrower format choices for English speaking audiences.

This result for foreign language stations is the ability to "cast a wider net". For instance, a typical Spanish language station may have listeners who are first generation immigrants who have deep cultural connections with their home countries. These same stations also have significant numbers of audience who consider themselves second or third generation immigrants who have assimilated almost completely or completely in American culture. What these 
first, second and third generation immigrants have in common is language, and ties to their home culture which also connects them to the foreign language radio station. These stations therefore have to broadcast to a wider range of audience and cannot narrowly focus programming in ways that English language radio stations have. Even though the Spanish station in this research had much success with 18 to 34 year olds, the station positions programming to cater to a family oriented 24 to 54 year old demographic. One of the successes this station shows is in reaching listeners across a variety of age groups and experiences within the Spanish speaking community.

A striking difference in the rates of adoption of new media practices by foreign language audiences was pointed out by one respondent. Although this station reported that many of the audience was slower to adopt new media technologies, many of the listeners were current with technology. This phenomenon points to the need for Spanish language radio to keep up with current trends in new media technology.

Expressed by respondents from all stations surveyed in this research was a need for balance between playing music and other non music entertainment content. What made programmers aware of the need for this balance between playing music and having compelling on air talent and content was in part, the emergence of the new media itself. A world wide platform such as the internet, and internet connected devices, can distribute content much more efficiently than terrestrial and satellite radio. 
New forms of curated channels and music playlisting technology has extended the availability of music. The consumer does not have to physically own the music he or she listens to anymore, but has greater access to music through the cloud than ever before. The consumer choice trends now indicate a preference for access to music rather than physical ownership of music. This change in relationship between ownership and access of music presents a new area for academic research with implications for media, business and culture.

Radio has rediscovered the importance of providing more than music and developing or redeveloping a sense of community, in order survive the realities of the digital landscape according to the research gathered here. This community does not have to be only local for radio going forward as social media has shown us. Community can be in the form of similar demographic and lifestyle groups that range across the globe. Radio channels that only stream or are otherwise internet only can develop community without geographic identity.

New media music technologies with audioscrobbling abilities, or the viral behaviors of the posting and sharing of YouTube videos threatened to make new media the primary place for audience to learn of new music. New media itself provided an answer to this challenge, such as radio's use of Shazam's analytics to identify new trends in musical interest by audiences. The capability of Shazam to to show regional definition can also help radio define and develop local musical preferences. This new media tool has the ability to enhance radio's efforts in maintaining local identities. Radio was, and still is a good source for 
people to be introduced to new music according to the respondents in this research.

According to the respondents, radio is perceived by the listening public as a good value because it is free. Commercials and advertising can be one of the most annoying experiences about radio listening, but they do not have to be. Commercials can be entertaining and iconic, such as when the camel asks "guess what day it is?" in a radio commercial. A recent survey found that 80 percent of rock radio listeners $12+$ think listening to commercials is a fair price to pay for free programming on their favorite radio stations (Edison Research and Triton Digital). This relationship with the radio consumer was established long ago and consumers generally accept it.

Curated music channels that were once free may discover the pain of renegotiating the relationship with consumers our respondents reported. Curated music channel consumers must choose between paying for the service that was once free or accepting the introduction of advertising to keep their services free. It remains to be seen if the switch from a free curated channel to a freemium channel presents only short term or longer term effects for these businesses.

As pointed out in Chapter Four, contrary to predictions that listeners would be abandoning radio for new media technologies, radio listening persists among all age groups, with adults under 30 accepting radio as one of their media choices. Even in over 30 year olds, radio listening is part of the diet of media 
consumption. Our respondents report that one of the challenges for radio regarding these older listeners is one of perception rather than actual behaviors.

To overcome the perception in older demographics that radio is somehow out of style, radio must redouble efforts in promotion. These listeners may need even more reinforcement that radio has been and continues to be an integral part of their lives. Contests must be both family and adult oriented, providing prizes that are sometimes family oriented, but also providing prizes that allow for a night on the town, an occasional escape for working adults.

Stations targeting these older listeners also must find connections to their audiences beyond contesting. Showing these listeners that these stations are an integral part of their lifestyle, sharing the same interests, and being interested in the same concerns of their listeners. This can be done by news and lifestyle information, targeted entertainment reporting, stations attendance at promotional events compatible with over 30 lifestyles, and by unique connections provided by the air talents.

Stations targeting older listeners should also pay particular attention to talent development and retention. All respondents for this research pointed to radio personalities as crucial in setting the station apart from other stations and other new media. The air talent must cultivate connections with audiences, and stations must build long term loyalties by use of the connections these air personalities make with their audiences. Most importantly, stations must strive 
to retain air personalities who have forged successful connections with their audiences.

Radio station websites seem to be performing the function of promoting stations core business and reaching out to potential audience members. Websites surveyed are robust with blogs, extended videos, examples of social media, and contesting. Radio stations use websites and social media to reach potential audiences where they are, and try to draw them into the sphere of participation of stations on line and broadcast content.

Websites and social media are seen as a promotional platform, much like street promotions. During a traditional radio station remote or street promotion, station members encounter the public and for many of the members of the public, this may be the first contact with the station. Respondents to this research felt that digital promotions can accomplish a similar task through various social media platforms, drawing in people through social media shared with friends who may be unaware of the station.

One advantage of these digital promotions is that they are free. It costs nothing to set up Facebook or Instagram account, for instance. These platforms provide the station with basic analytics of likes, views, comments, shares, or thumbs up. Each of the respondents to the research commented on the importance these new analytics provide for their promotions and marketing departments. Because of the digital promotional tools stations are now adaptable to changes in audience interests and movement in the digital space. 
Radio can track early adoptions of trends in culture, both in what people choose in their digital platform preferences, and in the content displayed there.

The digital reach is larger than the broadcast reach. Live streams, simulcast broadcasts on digital media, curated channels, internet only radio, and the social media used by stations can be accessed and enjoyed by people outside the broadcast umbrella. This provides a means for listeners to access the station on a variety of platforms. The possibility for stations to increase penetration in market may be possible because of these new platforms. Listeners can share social media content with their friends who may be unaware of the station, but fall in the station's target demographic. The new digital landscape is also a place where stations need to keep up with listeners migration to new platforms. As potential audiences may be spending more time on smartphones and tablets, radio stations will have a presence these devices through the availability of apps.

During this research a similarity in websites was noted with stations within ownership groups. Ownership groups are promoting different and distinct brands and their websites should reflect a brand distinction. While many ownership brands have overlapping audience, and therefore a similar look and function, some brands within ownership groups have distinctly different audience targets in the form of age demographics, lifestyle and interests. It should be important for ownership groups to present websites with a different look and feel to different audiences. Broadcast owners need to ask themselves if audiences brand 
preferences break along format lines, such as a preference of a hip-hop station over a Top 40 station or rather, do audience preferences break along ownership lines, such as one ownership group over another?" If the answer is brand preference rather than loyalty to the ownership group, then ownership groups should do a better job of making the websites of their various brands look and function differently. Ownership groups that have regional or national program directors for distinct formats may want to think of a similar business model for their digital divisions, such as format brand distinct digital divisions where the digital services department has format specific sub-divisions.

When it comes to the posts on stations websites and social media, the content must be integral to the format brand. Respondents in this research stated the positive effects of the ability of these posts to go viral. The recommendation of this research is to craft posts that do the work of promoting the station brand or image, much in the same way that on air imaging and promotions reinforce the stations' brand to the listener. Website and social media posts also posses the ability to draw internet and social media users back to the station, and introduce new potential audience members to the station. Because of ability of social media to reinforce brand identity and reach new audiences, the content of social media posts should effectively brand the station such as the following example (See Figure 1). 


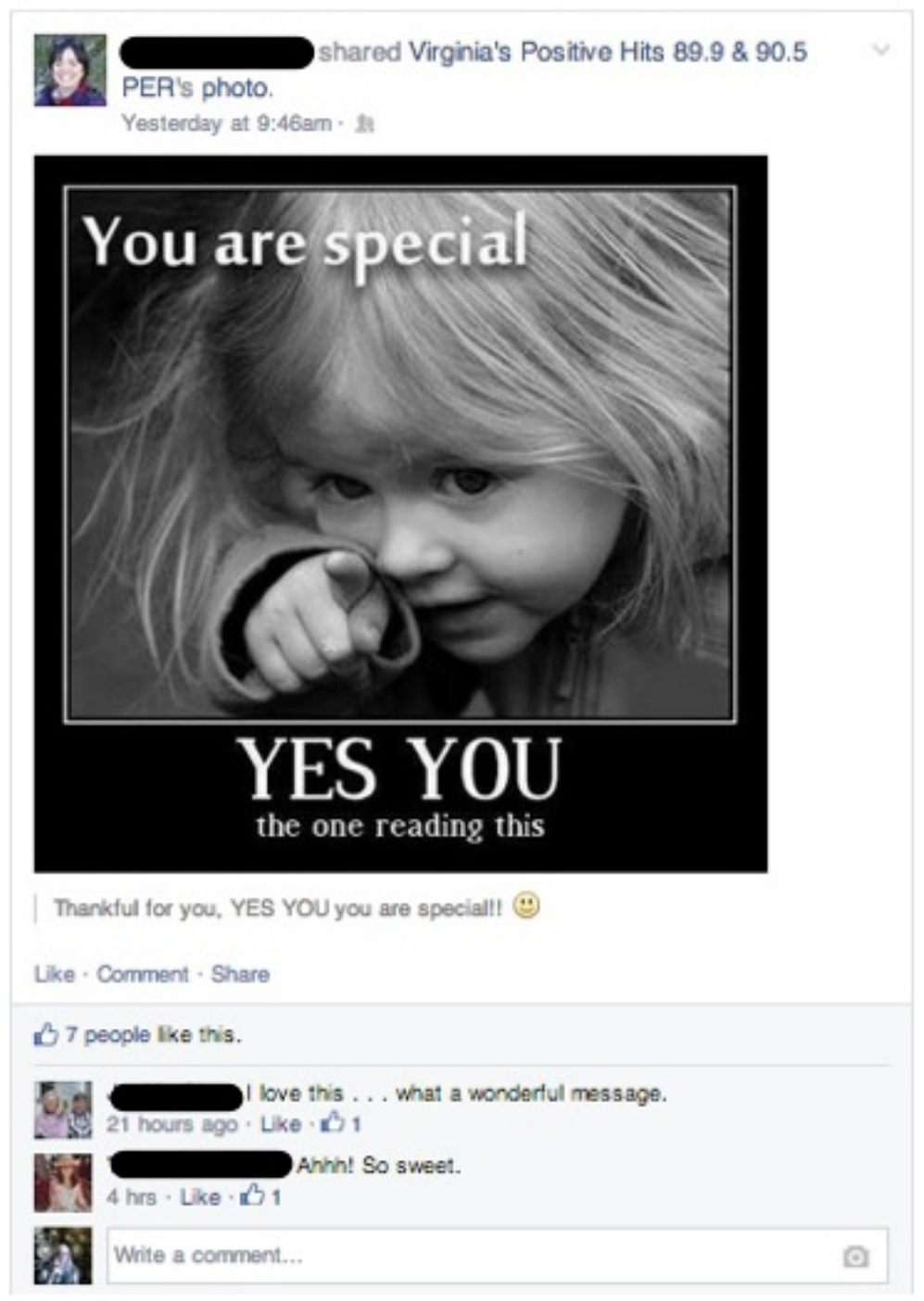

Fig. 1. Shared Facebook Photo, Facebook (Virginia's Positive Hits 89.9 \& 90.5 PER)

The emergence of these new media tools has moved radio and radio listening to the digital landscape. Radio now has a presence on the new media technological platforms used today, where much of the audience is, as the public is in the midst of a great media migration to digital platforms. One fertile ground 
for platform migration is in in-car listening. Drivers and passengers are now used to $A M / F M$ receivers, in dash CD players, some cars come with satellite, HD radio, GPS, and many after market devices are now available. The first mass produced consumer vehicle with in-dash $4 G$ capability is here now, the Audi A3 (Howard). During the 2014 Consumer Electronics Show General Motors announced several models would be $4 \mathrm{G}$ capable by model year 2015, with Ford also looking at similar technology. The functionality of these early devices, and the usefulness of these early devices for consumers will be open for debate. Interestingly, the Audi vehicle is also a wireless hotspot allowing existing smartphones, tablets and laptops to use existing applications while the user is in the vehicle. Consumers may want the same or similar functionality in dash that they can get now on their mobile devices when in the same car. The functionality of current mobile technology may migrate directly over to the dashboard of the car of the near future. Right now, the cost of the data plan may be prohibitive for many consumers (Howard), but the technology has arrived and some automobile manufacturers are beginning to install this technology. It remains to be seen if either consumers are willing to pay for expanded data plans or if market prices for data plans adjust to a level acceptable for a significant amount of consumers. As automobiles become more and more sophisticated, the in dash car radio may be replaced by the same computer and mobile connection technology available today on our mobile devices. With these new media tools radio is using and 
developing today, such as radio playing apps and streaming, radio is carving out a space in this new digital landscape.

Obviously, radio has not ignored the emerging technologies, nor can it afford to. Satellite radio needs to pay particular attention to this. When true internet connectivity arrives in most automobiles, the need for a satellite channel dedicated to a radio receiver becomes unnecessary for the consumer. For consumers, the added cost of a satellite subscription service may be unnecessary when music channels and on line radio is available in the digital dashboard. Satellite providers are currently maintaining an expensive satellite network that will be rendered obsolete when these new wireless technologies become available in most automobiles. Satellite providers currently have an online app that is auxiliary to its core business of broadcast. The on line app may become the core business of satellite radio once the digital dash becomes the prevailing in car entertainment device.

With the migration of radio listening to a more app based technology, another challenge in the measurement of radio listening is presented. Currently many radio stations use their internet streams as an alternative revenue source apart from their core broadcast signals. These stations replace the broadcast commercials on their streams with a separate set of commercials. This allows stations a higher total of number of commercial inventory when combining the broadcast commercials with the streaming commercials. 
Under current protocols, Nielsen encodes broadcasts so they may be measured by PPM technology. When stations present different content on their live streams than content on their broadcast channels, they are not allowed to use the same encoded identification on their streams. Stations must pay extra for both encoding on broadcast channels and streaming channels. If stations choose not to encode their streaming channels for financial reasons the result will be an inaccuracy of audience measurement as stations cannot combine audience numbers from live streams and broadcasts.

As the extra revenue from live streams present a significant alternative revenue source for stations, broadcasters are faced with a dilemma. The choice is between an accurate measurement of combined listening of broadcasts and streams, or the added revenue from the alternative content presented on the live streams. Many stations for obvious bottom line concerns, choose the latter alternative.

If radio stations are choosing to not encode their streams in favor of the added revenue these streams allow for, then what is the harm to radio? The harm to radio is possibly an under reporting of actual radio listening. Basic ratings information does get reported in the trade press and eventually this reporting makes it to the popular press. This information could possibly be reinforcing the notion among many in the listening public that radio listening is not as robust as the actual listening of both broadcasts and streams. Currently radio may be more popular than the public realizes, especially when broadcast 
and streaming audience numbers are combined. For a medium that is relying so heavily on new media for promoting radio listening, radio is not maximizing the full promotional value of these new media in favor of alternative revenue, to the detriment of the act of promoting radio as a medium.

There are a few considerations to overcome when choosing between encoding or not encoding radio stations internet streams. Obviously broadcasters could choose to encode their streams now. That is not being done now for the reasons described earlier. Ratings services might consider allowing stations to encode their streams with an alternative set of encoding signals. This would allow for stations to piggyback their streaming data on to their broadcast data. The press could use the survey data from the broadcasts and streams to show an adjusted level of combined listening. However, as stations use audience numbers to derive the rate they charge for advertising, the adjusted combined figures could not be used for setting ad rates, but the component parts of the adjusted measurement could be separated to set separate ad rates for broadcasts and streams.

There might become a point where listening is such more prevalent on streams that radio stations would want accurate audience data from their streams. With the combination of internet connectivity and the emergence of a digital dashboard, and the broader reach the internet allows for compared to the broadcast transmission, there may come a time when there are more listeners on the stream than on the broadcast signal. This might prompt the industry, both 
radio broadcasters and those involved in audience measurement, to adjust methodologies to accurately measure listening on the streams.

Another indirect option to overcome the underreporting of radio listening over internet connected devices is to add a radio receiver to mobile devices. There is some reported interest in including a radio receiver in these devices. The 2014 Infinite Dial Research found that 17 percent of persons 12 years old and older would listen to radio "a lot more" if cell phones had an FM receiver (Edison Research and Triton Digital). The fact that the industry is researching the possibility of tuners in cell phones points to the radio industry's interest in this becoming an reality. One obstacle for including a radio tuner in mobile devices is the added cost of providing a tuner would be passed on to the consumer buying a mobile device. With public interest in mobile devices equipped with an FM tuner at these relatively low levels, it may be unlikely that no amount of radio industry lobbying could persuade cell phone makers to include FM tuners.

The radio industry might actively lobby the FCC to mandate inclusion of FM tuners in cell phones as a public safety issue. During a storm or earthquake it is possible for the interruption of cellular service. Radio broadcasts received over FM tuners in cell phones and tablets would be one way to keep the public informed in the event of an emergency. Radio's Emergency Alert System is designed to do just that, keep the public informed in the event of an emergency. When internet connected mobile devices such as cell phones, tablets, and internet connected automobiles are rendered ineffective in an emergency 
because of a collapse of some portions of the electrical grid or wireless network, radio broadcasts would remain a robust network to inform the public. If these mobile devices were to also have an radio tuner installed, the public would have access to the EAS system and the necessary information the system provides. It would take regulation from the FCC to mandate radio tuners for wireless devices, business lobbying from both sides of this issue would probably be vigorous.

While there are challenges presented by these new media technologies, there are other opportunities for broadcasters presented by these technologies. The multi platform capability of Clear Channel Media and Entertainment's iHeart radio provides users with simulcast radio, internet only radio broadcasts and curated music channels. The strategy here is to provide one central app that provides a variety of programming the public wants, and is available on all the mobile platforms the public is using. Clear Channel is also an established radio broadcaster with strong ties to the music industry, and can draw on the many resources of the company for both content and monetization. This can allow iHeart to compete with other apps such as Pandora, Spotify and iTunes Radio. As pointed out in Table 12, Pandora remains the most popular curated music channel by far and iHeart still has some work to do in terms of popularity and use, but as the app marketplace matures the strategy of having a useful single multi function app may be more convenient for consumers than having to switch between multiple single use apps. The iHeart app is well positioned to become the music listening "appliance" of the future much as the AM/FM tuner with a CD 
player is the music listening appliance of the recent past. This is not to say that iHeart radio has a distinct market advantage now or in the future, or exclude another entrepreneur from providing a better music content application, but the idea of one app that offers multi functionality providing the consumer with one easy to use place for broadcast and music entertainment is an intriguing idea.

Clear Channel's decision not to charge for it's curated channels when Pandora and other apps are now introducing customers to the choice of subscription versus commercials, shows that Clear Channel can use the resources of the company to cover research and development of it's iHeart app, as well as help the early ramp up of the use of the app. Just as with the broadcast industry itself, Clear Channel can become a strong competitor on the digital space when dealing with smaller start up companies. It is easy to draw a comparison to the consolidation of radio ownership and the business efficiencies created by consolidation, to the consolidation of the number of providers of internet music and entertainment, but there might be a weeding out of music channel providers as the digital landscape progresses. Stand alone music channel providers might wish to consider partnering with broadcast and online radio music providers to provide multi functionality in their apps as well. Radio and satellite broadcasters might also want to consider a partnership with these stand alone curated channels as a way to stake out a place on the digital landscape. 
These new media technologies have provided many challenges and new opportunities for radio. The migration of public's interest in social media and digital platforms challenges traditional media to keep up with new trends in media culture. As stated before, radio must embrace these new trends and find ways to use them to advantage.

Another challenge for radio is in perception. The perception that radio is not an up to date, or is an "uncool" medium, particularly with listeners who have witnessed the birth of these new media tools in their lifetimes. Radio needs to face the challenge of promoting well to all listeners, but in particular there is a challenge of promoting radio listening to over 30 year old listeners as noted by some of the respondents to this research.

There will be yet unforeseen new media tools and platforms which will eventually become available to the public. Radio needs to be able to adapt to these new media, as well as adapt to the new media and platforms visible on the horizon such as the wireless connected automobile and the digital entertainment dashboard it may support. These new and yet undiscovered new media tools also provide many opportunities for radio such and a new and easy avenues of availability to potential audiences via social media. The various social media platforms provide a new landscape for promoting radio listening through contesting, listener awareness, and the potential of drawing new listeners in to radio. These media also provide a potential in audience increase in reach and 
size via digital solutions accessed over the internet. Radio also benefits from new audience feedback tools provided by social media and music identifier programs.

The ability for new media to provide connections with current audiences and the ability to connect with potential audiences over the digital landscape has beneficial effects for radio. Through these new media radio can connect with, promote to, and reach audiences in a way not possible before the advent of these new technologies. These new media technologies and the social behaviors they promote is keeping radio "in tune" with audiences needs, desires and changes in culture going forward. To paraphrase Marshall McLuhan, the new media which at first challenged and oppressed radio, has reshaped and revitalized radio. 


\section{Work Cited}

99.7 NOW. "99.7 [NOW!] All the Hits, Pop News, Artists, Celebrities." Web. 2 May 2014. <http://997now.cbslocal.com/>

Adams, Michael. "Broadcasting's Forgotten Father, the Charles Herrold Story". Web. 29 April 2013. <http://youtu.be/5nIVv_2cGaQ?t=25m00s>

AddThis. "Content Engagement Done Right", Web 3 May 2014. < $\underline{\text { http:// }}$ www.addthis.com/about>

Albarran, Alan B., et al. "“What Happened to our Audience?" Radio and New Technology Uses and Gratifications among Young Adult Users." Journal of Radio Studies 14.2 (2007): 92-101. Web.

All Access. "Nielsen Markets, \#4 San Francisco, CA" All Access Music Group. Web. 15 Apr. 2014. <http://www.allaccess.com/nielsen/q/market/108/sanfrancisco-ca>

Arbitron/Edison Research, "PPM Panels: A Guidebook for Arbitron Authorized Users." Arbitron Inc. (2013) PDF File.

Arbitron/Edison Research, "Radio Today 2011, How America Listens to Radio." Web. 29 Sept. (2012) <http://www.arbitron.com/downloads/

Radio_Today_2011.pdf $>$

Arbitron/Edison Research, "Radio Today 2012, How America Listens to Radio." Arbitron Inc. (2013) PDF File.

Arbitron/Edison Research, "Radio Today 2012, How America Listens to Radio." Arbitron Inc. (2013) PDF File.

Bohm, David. "On Communication." John Stewart, Bridges Not Walls: A Book About Interpersonal Communication (9th), New York: McGraw-Hill Companies(2006) PDF File. 
Bosker, Bianca. "Teens are Leaving Facebook for Facebook." Huffington Post. Web 11 Apr 2014. <http://www.huffingtonpost.com/2014/04/11/teensfacebook_n_5127455.html?utm_hp_ref=technology>

Brecht, Bertolt. "The Radio as an Apparatus of Communication." Brecht on Theatre (1932): 51-3. Web.

Carr, David. "Howard Stern, Silenced in Some Cities, Gains in Some Others". Web. 4 Mar 2014. <http://www.nytimes.com/2004/07/01/arts/howard-sternsilenced-in-some-cities-gains-some-others.html>

Carroll, John. "Internet Catches More of Americans' Time". Gallup. Web. 1 April $2014<$ http://www.gallup.com/poll/20815/Internet-Catches-MoreAmericans-Time.aspx $>$

Chan-Olmsted, S. M., and L. S. Ha. "Internet Business Models for Broadcasters: How Television Stations Perceive and Integrate the Internet." Journal of Broadcasting \& Electronic Media 47.4 (2003): 597-616.

Clear Channel Music and Entertainment. "Welcome to iHeart Radio". Web. 21 Mar 2014. < http://news.iheart.com/articles/about-iheartradio-390884/ welcome-to-iheartradio-6906244/>

Collman, Ashley and Warren, Lydia. "Behind the scenes with Batkid: New video shows how Make-a-Wish foundation turned San Francisco into Gotham City to fulfill 5-year-old cancer survivor's dream". 2013. Web. 4 May 2014. $<$ http://www. dailymail.co.uk/news/article-2508761/Batkids-origin-storyVideo-shows-Make-Wish-foundation-turned-San-Francisco-GothamCity.html>

Corwin, Norman, perf. Empire of the Air: The Men Who Made Radio. Dir. Ken Burns. PBS Home Video. 1991. DVD.

Dunning, John. "On the air: The encyclopedia of old-time radio". Oxford University Press, 1998. 30-31.

Edison Research and Triton Digital. “The Infinite Dial 2014”. Web. 5 Mar 2014. $<$ http://www.edisonresearch.com/wp-content/uploads/2014/03/The-InfiniteDial-2014-from-Edison-Research-and-Triton-Digital.pdf> 
Edison Research and Triton Digital. "The Infinite Dial 2014, A Look at Rock P1s". Web. 9 May 2014.<http://www.edisonresearch.com/wp-content/uploads/ 2014/05/InfiniteDial2014-Rock-Format.pdf>

Ferguson, D. A., C. F. Greer, and M. E. Reardon. "Uses and Gratifications of MP3 Players by College Students: Are iPods More Popular than Radio?" Journal of Radio Studies 14.2 (2007): 102-21

Howard, Bill. "CES 2014: 4G cars usher in the era of the seriously connected automobile". Extreme Tech. (2014). Web. 20 May 2014. < http:// www.extremetech.com/extreme/174287-ces-2014-4g-cars-usher-in-theera-of-the-seriously-connected-automobile>

Howard, Bill. "Audi A3 is first car with embedded 4G LTE - but will owners go broke streaming movies?". Extreme Tech. (2014). Web. 20 May 2014. $<$ http://www.extremetech.com/extreme/178416-audi-a3-is-first-car-withembedded-4g-lte-but-will-owners-go-broke-streaming-movies>

KISS-FM San Francisco. "98.1 KISS-FM San Francisco Bay’s Old School!". Web. 2 May 2014. <http://www.981kissfm.com/main.html>

KMEL-FM San Francisco. "106 KMEL San Francisco's Home for Hip Hop and R\&B!". web. 2 May $2014<$ http://www.kmel.com/main.html>

Knopper, Steve. "Can Shazam Predict the Next Big Hit?". Rolling Stone. (2014). Web. 4 May 2014.<http://www.rollingstone.com/music/news/can-shazampredict-the-next-big-hit-20140220>

LA RAZA San Francisco. "93.3 FM LA RAZA San Francisco". Web. 2 May 2014. $<$ http://yosoyraza.com/>

Lefsetz, Bob. "Radio Digs Its Own Grave as Cultural Currents Shift". Web. 5 Mar 2014. <http://variety.com/2013/music/news/radio-digs-its-own-grave-ascultural-currents-shift-1200500285/>

Lopez, Korina. "Shazam Predicts the Top 10 Songs of the Summer". USA Today. (2013) Web. 4 May 2014. <http://www.usatoday.com/story/life/music/ 2013/06/04/shazam-predicts-top-summer-songs/2384983/> 
Manuel, Jon. "Thank you, Batkid, for saving the City!!!". (2013) Web. 4 May 2014. $<$ http://www.1013.com/onair/jonmanuels-blog-45666/thank-you-batkid-forsaving-the-11832853/>

Merriam-Webster. "The Free Merriam-Webster Dictionary”. Web 14 Mar 2014. ,http://www.merriam-webster.com/dictionary/narrowcasting>

McLuhan, Marshall. “Understanding Media: The Extensions of Man”. Cambridge: MIT press, 1964. Print.

Munson, Wayne. "All talk: The talkshow in media culture". Temple University Press, 1993. 26-27.

Oxford University Press. "Oxford Dictionary". Web. 6 Mar 2014. <http:// www.oxforddictionaries.com/us/definition/american_english/radio>

Pew Internet \& American Life Project, Social Media \& Mobile Internet use among Teens and Young Adults. 2010. Web. PDF File.

Pew Research Center's Project for Excellence in Journalism. "The State of the News Media 2012". 2012. Web. PDF File.<http://stateofthemedia.org/ 2012/mobile-devices-and-news-consumption-some-good-signs-forjournalism/>

Pitts, M. J., and R. Harms. "Radio Websites as a Promotional Tool." Journal of Radio Studies 10.2 (2003): 270-82.

Potter, R. F. "Give the People what they Want: A Content Analysis of FM Radio Station Home Pages." Journal of Broadcasting \& Electronic Media 46.3 (2002): 369-84.

Radio Advertising Bureau. "Annual Radio Revenue Trends". 12 April 2014. Web. $<$ http://www.rab.com/public/pr/rev-pr.cfm?section=press $>$

Rainie, Lee. "Internet, Broadband and Cell Phone Statistics". Pew Internet \& Life Project, Jan. 2010. Web. PDF File. <http://www.pewinternet.org/files/oldmedia//Files/Reports/2010/PIP_December09_update.pdf> 
SF Gate Blog. "Follow Batkid's Adventure”. 2013. Web. 4 May 2014. $<$ http://blog.sfgate.com/ stew/2013/11/15/follow-batkids-adventure/>

Shazam. "Company Information". Web. 4 May 2014. <http://www.shazam.com/music/web/about.html>

Star 101.3 San Francisco. "Star 101.3 San Francisco's Variety from the 90's, 2000's and Today!". Web. 2 May 2014. <http://www.1013.com/main.html>

Stern, Howard. "Howard Stern (HowardStern) on Twitter. Web 4 mar 2014. $<$ https://twitter.com/HowardStern>

University of Southern California. "The 2013 Digital Future Report". USC Annenberg School Center for the Digital Future. 2013. Web. PDF File. $<$ http://www.digitalcenter.org/>

Virginia's Positive Hits 89.9 \& 90.5 PER. "You Are Special" 2014. Facebook. Facebook: Karen Abramson News Feed. 2014. Web. 27 Apr 2014.

WILD 94.9. "Wild 94.9 The Bay's \#1 Hit Music Station!". Web. 2 May 2014.<http:// www.wild949.com/main.html> 